\title{
All Roads Lead to Rome: Tuning the Luminescence of a Breathing Catenated Zr-MOF by Programmable Multiplexing Pathways
}

Cheng-Xia Chen ${ }^{\ddagger}$, Zhang-Wen Wei ${ }^{\ddagger}$, Chen-Chen Cao, Shao-Yun Yin, Qian-Feng Qiu, Neng-Xiu Zhu, Yang-Yang Xiong, Ji-Jun Jiang, Mei Pan* and Cheng-Yong Su

MOE Laboratory of Bioinorganic and Synthetic Chemistry, Lehn Institute of Functional Materials, School of Chemistry, Sun Yat-Sen University, Guangzhou 510275, China. 


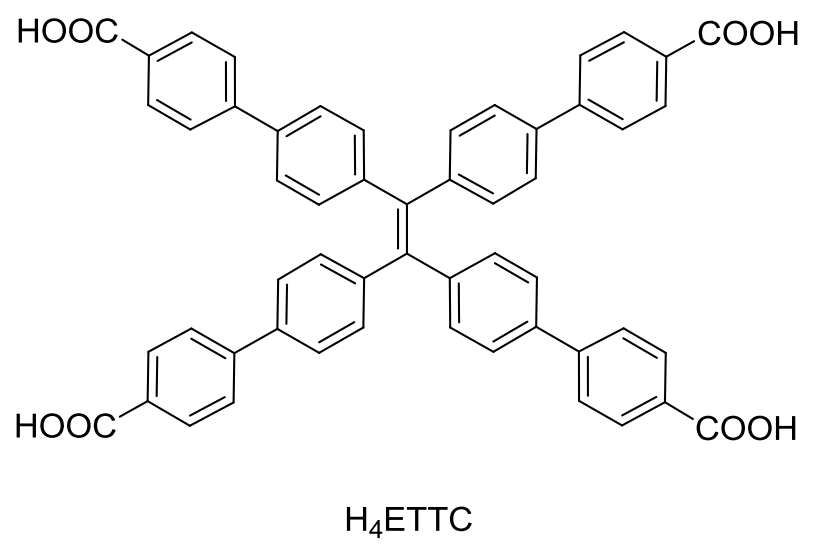

Scheme S1 The structure of $\mathbf{H}_{4}$ ETTC. 
Table S1 Crystallographic data for LIFM-114, LIFM-114-DCM, LIFM-114-EtOH

LIFM-114-Et 2 O, LIFM-114-MeOH, LIFM-114-Toluene, LIFM-114-40 C, LIFM-

$114-60^{\circ} \mathrm{C}, \mathrm{LIFM}-114-80^{\circ} \mathrm{C}$.

\begin{tabular}{|c|c|c|c|}
\hline Compound & LIFM-114 & $\begin{array}{c}\text { LIFM-114- } \\
\text { DCM }\end{array}$ & $\begin{array}{c}\text { LIFM-114- } \\
\text { EtOH }\end{array}$ \\
\hline CCDC No. & 1838330 & 1838332 & 1838333 \\
\hline Formula & $\mathrm{C}_{108} \mathrm{H}_{64} \mathrm{O}_{32} \mathrm{Zr}_{6}$ & $\mathrm{C}_{108} \mathrm{H}_{64} \mathrm{O}_{32} \mathrm{Zr}_{6}$ & $\mathrm{C}_{108} \mathrm{H}_{64} \mathrm{O}_{32} \mathrm{Zr}_{6}$ \\
\hline Formula Weight & 2420.91 & 2420.91 & 2420.91 \\
\hline Shape / Color & $\begin{array}{c}\text { Rod/ } \\
\text { Light green }\end{array}$ & $\begin{array}{c}\text { Rod/ } \\
\text { Light green }\end{array}$ & $\begin{array}{c}\text { Rod/ } \\
\text { Light green }\end{array}$ \\
\hline Crystal System & Orthorhombic & Orthorhombic & Orthorhombic \\
\hline Space Group & Fmmm & Cmmm & $\mathrm{Cmcm}$ \\
\hline$T(\mathrm{~K})$ & 150(2) & $150(2)$ & 150(2) \\
\hline$a(\AA)$ & $28.8004(15)$ & $21.4419(8)$ & $24.4853(11)$ \\
\hline$b(\AA)$ & $41.0306(17)$ & $42.3169(10)$ & $42.1654(14)$ \\
\hline$c(\AA)$ & $16.0688(7)$ & $17.9262(5)$ & $17.1403(6)$ \\
\hline$\alpha / \beta / \gamma\left(^{\circ}\right)$ & $90 / 90 / 90$ & $90 / 90 / 90$ & $90 / 90 / 90$ \\
\hline$V\left(\AA^{3}\right)$ & $18988.5(15)$ & $16265.4(8)$ & 17696.2(12) \\
\hline$Z$ & 4 & 4 & 4 \\
\hline$D_{\text {calc }}\left(\mathrm{g} / \mathrm{cm}^{3}\right)$ & 0.847 & 0.989 & 0.909 \\
\hline$\mu\left(\mathrm{mm}^{-1}\right)$ & 2.976 & 3.474 & 3.193 \\
\hline$F(000)$ & 4832.0 & 4832.0 & 4832.0 \\
\hline$R_{\text {int }}$ & 0.0239 & 0.0414 & 0.0586 \\
\hline Reflections collected / unique & $9705 / 4062$ & $18939 / 7377$ & $26316 / 7543$ \\
\hline Completeness to theta & $96.6 \%$ & $97.9 \%$ & $97.6 \%$ \\
\hline Data / Restraints / parameters & $4062 / 6 / 211$ & $7377 / 643 / 481$ & $7543 / 172 / 411$ \\
\hline$R_{l}[\mathrm{I}>2 \sigma(\mathrm{I})]$ & 0.0444 & 0.1295 & 0.0706 \\
\hline$w R_{2}[\mathrm{I}>2 \sigma(\mathrm{I})]$ & 0.1427 & 0.3874 & 0.1986 \\
\hline$R_{l}$ (all data) & 0.0474 & 0.1428 & 0.0958 \\
\hline$w R_{2}$ (all data) & 0.1457 & 0.4043 & 0.2197 \\
\hline GOF & 1.130 & 1.692 & 1.066 \\
\hline
\end{tabular}




\begin{tabular}{|c|c|c|c|}
\hline Compound & $\begin{array}{l}\text { LIFM-114- } \\
\mathrm{Et}_{2} \mathrm{O}\end{array}$ & $\begin{array}{c}\text { LIFM-114- } \\
\text { МeОН }\end{array}$ & $\begin{array}{c}\text { LIFM-114- } \\
\text { Toluene }\end{array}$ \\
\hline CCDC No. & 1838334 & 1838335 & 1838336 \\
\hline Formula & $\mathrm{C}_{108} \mathrm{H}_{64} \mathrm{O}_{32} \mathrm{Zr}_{6}$ & $\mathrm{C}_{108} \mathrm{H}_{64} \mathrm{O}_{32} \mathrm{Zr}_{6}$ & $\mathrm{C}_{108} \mathrm{H}_{64} \mathrm{O}_{32} \mathrm{Zr}_{6}$ \\
\hline Formula Weight & 2420.91 & 2420.91 & 2420.91 \\
\hline Shape / Color & $\begin{array}{c}\text { Rod/ } \\
\text { Light green }\end{array}$ & $\begin{array}{c}\text { Rod/ } \\
\text { Light green }\end{array}$ & $\begin{array}{c}\text { Rod/ } \\
\text { Light green }\end{array}$ \\
\hline Crystal System & Orthorhombic & Orthorhombic & Orthorhombic \\
\hline Space Group & $\mathrm{Cmmm}$ & Cmma & $\mathrm{Cmcm}$ \\
\hline$T(\mathrm{~K})$ & $150(2)$ & $150(2)$ & $150(2)$ \\
\hline$a(\AA)$ & $20.557(2)$ & $22.0159(12)$ & $26.6952(15)$ \\
\hline$b(\AA)$ & $42.7525(17)$ & $42.2419(14)$ & $41.2943(11)$ \\
\hline$c(\AA)$ & $17.8758(7)$ & 17.8711(5) & $16.8339(6)$ \\
\hline$\alpha / \beta / \gamma\left(^{\circ}\right)$ & $90 / 90 / 90$ & $90 / 90 / 90$ & $90 / 90 / 90$ \\
\hline$V\left(\AA^{3}\right)$ & $15710.4(18)$ & $16620.0(12)$ & $18557.0(13)$ \\
\hline$Z$ & 4 & 4 & 4 \\
\hline$D_{\text {calc }}\left(\mathrm{g} / \mathrm{cm}^{3}\right)$ & 1.024 & 0.968 & 0.867 \\
\hline$\mu\left(\mathrm{mm}^{-1}\right)$ & 3.597 & 3.400 & 3.045 \\
\hline$F(000)$ & 4832.0 & 4832.0 & 4832.0 \\
\hline$R_{\text {int }}$ & 0.0429 & 0.0308 & 0.0497 \\
\hline Reflections collected / unique & $14971 / 6735$ & $15692 / 7162$ & $22133 / 8263$ \\
\hline Completeness to theta & $96.4 \%$ & $96.2 \%$ & $97.6 \%$ \\
\hline Data / Restraints / parameters & $6735 / 733 / 765$ & $7162 / 6 / 344$ & $8263 / 48 / 411$ \\
\hline$R_{l}[\mathrm{I}>2 \sigma(\mathrm{I})]$ & 0.1298 & 0.0507 & 0.0808 \\
\hline$w R_{2}[\mathrm{I}>2 \sigma(\mathrm{I})]$ & 0.3497 & 0.1498 & 0.2438 \\
\hline$R_{l}$ (all data) & 0.1492 & 0.0594 & 0.0962 \\
\hline$w R_{2}$ (all data) & 0.3751 & 0.1571 & 0.2535 \\
\hline GOF & 1.545 & 1.067 & 1.065 \\
\hline
\end{tabular}




\begin{tabular}{|c|c|c|c|}
\hline Compound & $\begin{array}{c}\text { LIFM-114- } \\
40^{\circ} \mathrm{C}\end{array}$ & $\begin{array}{c}\text { LIFM-114- } \\
60^{\circ} \mathrm{C}\end{array}$ & $\begin{array}{c}\text { LIFM-114- } \\
80^{\circ} \mathrm{C}\end{array}$ \\
\hline CCDC No. & 1858052 & 1858053 & 1858054 \\
\hline Formula & $\mathrm{C}_{108} \mathrm{H}_{64} \mathrm{O}_{32} \mathrm{Zr}_{6}$ & $\mathrm{C}_{108} \mathrm{H}_{64} \mathrm{O}_{32} \mathrm{Zr}_{6}$ & $\mathrm{C}_{108} \mathrm{H}_{64} \mathrm{O}_{32} \mathrm{Zr}_{6}$ \\
\hline Formula Weight & 2420.91 & 2420.91 & 2420.91 \\
\hline Shape / Color & $\begin{array}{c}\text { Rod/ } \\
\text { Light green }\end{array}$ & $\begin{array}{c}\text { Rod/ } \\
\text { Light green }\end{array}$ & $\begin{array}{c}\text { Rod/ } \\
\text { Light green }\end{array}$ \\
\hline Crystal System & Orthorhombic & Orthorhombic & Orthorhombic \\
\hline Space Group & Cmmm & Cmme & Cmmm \\
\hline$T(\mathrm{~K})$ & $150(2)$ & $150(2)$ & $150(2)$ \\
\hline$a(\AA)$ & $25.7916(15)$ & $21.8356(8)$ & $21.0637(7)$ \\
\hline$b(\AA)$ & $41.7841(11)$ & $42.279(2)$ & $42.3687(11)$ \\
\hline$c(\AA)$ & $16.8545(4)$ & $17.9114(3)$ & $18.0144(4)$ \\
\hline$\alpha / \beta / \gamma\left(^{\circ}\right)$ & $90 / 90 / 90$ & $90 / 90 / 90$ & $90 / 90 / 90$ \\
\hline$V\left(\AA^{3}\right)$ & $18163.7(12)$ & $16535.4(11)$ & $16076.8(8)$ \\
\hline$Z$ & 4 & 4 & 4 \\
\hline$D_{\text {calc }}\left(\mathrm{g} / \mathrm{cm}^{3}\right)$ & 0.885 & 0.972 & 1.000 \\
\hline$\mu\left(\mathrm{mm}^{-1}\right)$ & 3.111 & 3.418 & 3.515 \\
\hline$F(000)$ & 4832.0 & 4832.0 & 4832.0 \\
\hline$R_{\text {int }}$ & 0.0303 & 0.0282 & 0.0402 \\
\hline Reflections collected / unique & $19342 / 8272$ & $18750 / 7286$ & $17653 / 7306$ \\
\hline Completeness to theta & $97.8 \%$ & $97.8 \%$ & $97.1 \%$ \\
\hline Data / Restraints / parameters & $8272 / 728 / 543$ & $7286 / 511 / 344$ & $7306 / 950 / 554$ \\
\hline$R_{l}[\mathrm{I}>2 \sigma(\mathrm{I})]$ & 0.1139 & 0.0541 & 0.1360 \\
\hline$w R_{2}[\mathrm{I}>2 \sigma(\mathrm{I})]$ & 0.3225 & 0.1717 & 0.3562 \\
\hline$R_{l}$ (all data) & 0.1232 & 0.0595 & 0.1524 \\
\hline$w R_{2}$ (all data) & 0.3333 & 0.1767 & 0.3721 \\
\hline GOF & 1.078 & 1.1158 & 1.000 \\
\hline
\end{tabular}

\section{Note for LIFM-114 refinement}

The phenyl ring rotation produced disorder, so the occupancy of $\mathrm{C} 9, \mathrm{C} 10, \mathrm{C} 12, \mathrm{C} 13, \mathrm{C} 9 \mathrm{~A}$, C10A, C12A and C13A was set to $50 \%$. DFIX and FLAT were used to restrain the atoms. ISOR, DELU and SIMU were used to restrain the ADP refinement. The 921 restraints caused 755 refine parameters. The large pores contain highly disordered solvent molecules which cannot be determined. SQUEEZE treatment was applied and the squeezed void volume is $6291 \AA^{3}$, equivalent to $57.7 \%$ of the unit cell. The $\mathrm{R}_{1}$ value is 0.0876 without SQUEEZE treatment and 0.0444 with SQUEEZE treatment.

\section{Note for LIFM-114-DCM refinement}

The interpenetration networks can slide and so one set of framework is highly disordered and randomly appear in two positions. Thus the occupancy of C15-C29, C15A-C27A, O3, O4, O3A, $\mathrm{O} 4 \mathrm{~A}$ and $\mathrm{O} 9$ was refined as $50 \%$; the occupancy of $\mathrm{O} 10-\mathrm{O} 14, \mathrm{O} 14 \mathrm{~A}, \mathrm{Zr} 3, \mathrm{Zr} 4$ and $\mathrm{Zr} 5$ was set 
as $25 \%$. The phenyl ring rotation produced disorder, so the occupancy of $\mathrm{C} 9, \mathrm{C} 10, \mathrm{C} 12, \mathrm{C} 13, \mathrm{C} 9 \mathrm{~A}$, C10A, C12A and C13A was set to 50\%. DFIX and FLAT were used to restrain the atoms. ISOR, DELU and SIMU were used to restrain the ADP refinement. The 643 restraints caused 481 refine parameters. The large pores contain highly disordered solvent molecules which cannot be determined. SQUEEZE treatment was applied and the squeezed void volume is $7049 \AA^{3}$, equivalent to $43.3 \%$ of the unit cell. The $\mathrm{R}_{1}$ value is 0.1483 without SQUEEZE treatment and 0.1295 with SQUEEZE treatment.

\section{Note for LIFM-114-EtOH refinement}

The phenyl ring rotation produced disorder, so the occupancy of $\mathrm{C} 9, \mathrm{C} 10, \mathrm{C} 12, \mathrm{C} 13, \mathrm{C} 9 \mathrm{~A}$, C10A, C12A, C13A, C16, C17, C19, C20, C16A, C17A, C19A and C20A was set to 50\%. DFIX was used to restrain the atoms. ISOR, DELU and SIMU were used to restrain the ADP refinement. The 172 restraints caused 411 refine parameters. The large pores contain highly disordered solvent molecules which cannot be determined. SQUEEZE treatment was applied and the squeezed void volume is $9445 \AA^{3}$, equivalent to $53.4 \%$ of the unit cell. The $R_{1}$ value is 0.1058 without SQUEEZE treatment and 0.0706 with SQUEEZE treatment.

\section{Note for LIFM-114-Et ${ }_{2} \mathrm{O}$ refinement}

The interpenetration networks can slide and so one set of framework is highly disordered and randomly appear in four positions. Thus the occupancy of C15-C29, C15A-C27A, C15B-C27B, $\mathrm{C} 15 \mathrm{C}-\mathrm{C} 27 \mathrm{C}, \mathrm{O} 3, \mathrm{O} 4, \mathrm{O} 3 \mathrm{~A}, \mathrm{O} 4 \mathrm{~A}, \mathrm{O} 3 \mathrm{~B}, \mathrm{O} 4 \mathrm{~B}, \mathrm{O} 3 \mathrm{C}$ O4C, O9, O10, O13 - O16, Zr4 and Zr5 was refined as $25 \%$; the occupancy of $\mathrm{O} 11, \mathrm{O} 12, \mathrm{Zr} 3$ and $\mathrm{Zr} 6$ was set as $12.5 \%$. The phenyl ring rotation produced disorder, so the occupancy of $\mathrm{C} 3, \mathrm{C} 4, \mathrm{C} 6, \mathrm{C} 7, \mathrm{C} 3 \mathrm{~A}, \mathrm{C} 4 \mathrm{~A}, \mathrm{C} 6 \mathrm{~A}, \mathrm{C} 7 \mathrm{~A}, \mathrm{C} 9, \mathrm{C} 10, \mathrm{C} 12, \mathrm{C} 13$, C9A, C10A, C12A and C13A was set to $50 \%$. DFIX and FLAT were used to restrain the atoms. EADP, ISOR, DELU and SIMU were used to restrain the ADP refinement. The 733 restraints caused 765 refine parameters. The large pores contain highly disordered solvent molecules which cannot be determined. SQUEEZE treatment was applied and the squeezed void volume is $5422 \AA^{3}$, equivalent to $34.5 \%$ of the unit cell. The $\mathrm{R}_{1}$ value is 0.1488 without SQUEEZE treatment and 0.1298 with SQUEEZE treatment.

\section{Note for LIFM-114-MeOH refinement}

ISOR was used to restrain the ADP refinement. The 6 restraints caused 344 refine parameters. The large pores contain highly disordered solvent molecules which cannot be determined. SQUEEZE treatment was applied and the squeezed void volume is $8901 \AA^{3}$, equivalent to $53.6 \%$ of the unit cell. The $\mathrm{R}_{1}$ value is 0.0849 without SQUEEZE treatment and 0.0507 with SQUEEZE treatment. 


\section{Note for LIFM-114-Toluene refinement}

The phenyl ring rotation produced disorder, so the occupancy of $\mathrm{C} 9, \mathrm{C} 10, \mathrm{C} 12, \mathrm{C} 13, \mathrm{C} 9 \mathrm{~A}$, C10A, C12A, C13A, C16, C17, C19, C20, C16A, C17A, C19A and C20A was set to $50 \%$. DELU and SIMU were used to restrain the ADP refinement. The 48 restraints caused 411 refine parameters. The large pores contain highly disordered solvent molecules which cannot be determined. SQUEEZE treatment was applied and the squeezed void volume is $10377 \AA^{3}$, equivalent to $55.9 \%$ of the unit cell. The $\mathrm{R}_{1}$ value is 0.1135 without SQUEEZE treatment and 0.0808 with SQUEEZE treatment.

\section{Note for LIFM-114-40 ${ }^{\circ} \mathrm{C}$ refinement}

The interpenetration networks can slide and so one set of framework is highly disordered and randomly appear in four positions. Thus the occupancy of $\mathrm{C} 15-\mathrm{C} 41, \mathrm{O} 3-\mathrm{O} 7, \mathrm{O} 12, \mathrm{Zr} 4$ and $\mathrm{H}$ attached to these atoms was set to $50 \%$. The occupancy of $014-\mathrm{O} 17$ was set to $25 \%$. The occupancy of $\mathrm{Zr} 3$ and $\mathrm{Zr} 5$ was set to $12.5 \%$. The phenyl ring rotation produced disorder, so the occupancy of C9, C10, C12, C13, C9A, C10A, C12A and C13A was set to $50 \%$. DFIX and FLAT were used to restrain the atoms. ISOR, DELU and SIMU were used to restrain the ADP refinement. The 728 restraints caused 543 refine parameters. The large pores contain highly disordered solvent molecules which cannot be determined. SQUEEZE treatment was applied and the squeezed void volume is $8515 \AA^{3}$, equivalent to $46.9 \%$ of the unit cell. The $R_{1}$ value is 0.1423 without SQUEEZE treatment and 0.1232 with SQUEEZE treatment.

\section{Note for LIFM-114-60 ${ }^{\circ} \mathrm{C}$ refinement}

ISOR, DELU and SIMU were used to restrain the ADP refinement. The 511 restraints caused 344 refine parameters. The large pores contain highly disordered solvent molecules which cannot be determined. SQUEEZE treatment was applied and the squeezed void volume is $8807 \AA^{3}$, equivalent to $53.3 \%$ of the unit cell. The $\mathrm{R}_{1}$ value is 0.0986 without SQUEEZE treatment and 0.0595 with SQUEEZE treatment.

\section{Note for LIFM-114-80 ${ }^{\circ} \mathrm{C}$ refinement}

The interpenetration networks can slide and so one set of framework is highly disordered and randomly appear in four positions. Thus the occupancy of C15 - C27, C29-C41, O3 - O7, O15 and $\mathrm{H}$ attached to these atoms was set to $50 \%$. The occupancy of $\mathrm{C} 28, \mathrm{C} 42, \mathrm{O} 11-\mathrm{O} 14, \mathrm{O} 16, \mathrm{O} 17$, $\mathrm{Zr} 3-\mathrm{Zr} 5$ was set to $25 \%$. The phenyl ring rotation produced disorder, so the occupancy of $\mathrm{C} 9$, $\mathrm{C} 10, \mathrm{C} 12, \mathrm{C} 13, \mathrm{C} 9 \mathrm{~A}, \mathrm{C} 10 \mathrm{~A}, \mathrm{C} 12 \mathrm{~A}$ and C13A was set to $50 \%$. DFIX, SADI and FLAT were used to restrain the atoms. ISOR, DELU and SIMU were used to restrain the ADP refinement. The 950 restraints caused 554 refine parameters. The large pores contain highly disordered solvent molecules which cannot be determined. SQUEEZE treatment was applied and the squeezed void volume is $6816 \AA^{3}$, equivalent to $42.4 \%$ of the unit cell. The $\mathrm{R}_{1}$ value is 0.1894 without SQUEEZE treatment and 0.1524 with SQUEEZE treatment. 
Table S2 The results of PXRD Le Bail refinements.

\begin{tabular}{|c|c|c|c|c|c|}
\hline Compound & $\begin{array}{c}\text { LIFM-114cp } \\
\text { (LIFM-114- } \\
\left.\mathbf{1 0 0}^{\circ} \mathbf{C}\right)\end{array}$ & $\begin{array}{c}\text { LIFM-114- } \\
\mathbf{8 M P a}\end{array}$ & $\begin{array}{c}\text { LIFM-114- } \\
\mathbf{1 2 M P a}\end{array}$ & $\begin{array}{c}\text { LIFM-114- } \\
\mathbf{1 6 M P a}\end{array}$ & $\begin{array}{c}\text { LIFM-114- } \\
\mathbf{2 0 M P a}\end{array}$ \\
\hline Crystal System & Orthorhombic & Orthorhombic & Orthorhombic & Orthorhombic & Orthorhombic \\
\hline Space Group & $C m m m$ & $F m m m$ & $C m m m$ & $F m m m$ & $C m m m$ \\
\hline a $(\AA)$ & 23.962 & 21.642 & 21.167 & 21.238 & 26.347 \\
\hline $\mathrm{b}(\AA)$ & 45.579 & 43.694 & 45.256 & 45.158 & 42.191 \\
\hline $\mathrm{c}(\AA)$ & 14.244 & 18.072 & 16.789 & 16.663 & 14.195 \\
\hline $\mathrm{V}\left(\AA^{3}\right)$ & 15557.5 & 17090.0 & 16083.7 & 15981.4 & 15779.7 \\
\hline Temperature $(\mathrm{K})$ & 298 & 298 & 298 & 298 & 298 \\
\hline $2 \theta$ range $\left(^{\circ}\right)$ & $2-50$ & $2-50$ & $2-50$ & $2-50$ & $2-50$ \\
\hline $\mathrm{GOF}^{\circ}$ & 1.23 & 2.71 & 1.05 & 1.53 & 1.29 \\
\hline $\mathrm{R}_{\mathrm{p}}$ & 3.39 & 5.95 & 3.76 & 4.10 & 5.49 \\
\hline $\mathrm{R}_{\mathrm{wp}}$ & 4.68 & 9.50 & 4.86 & 5.66 & 7.09 \\
\hline
\end{tabular}



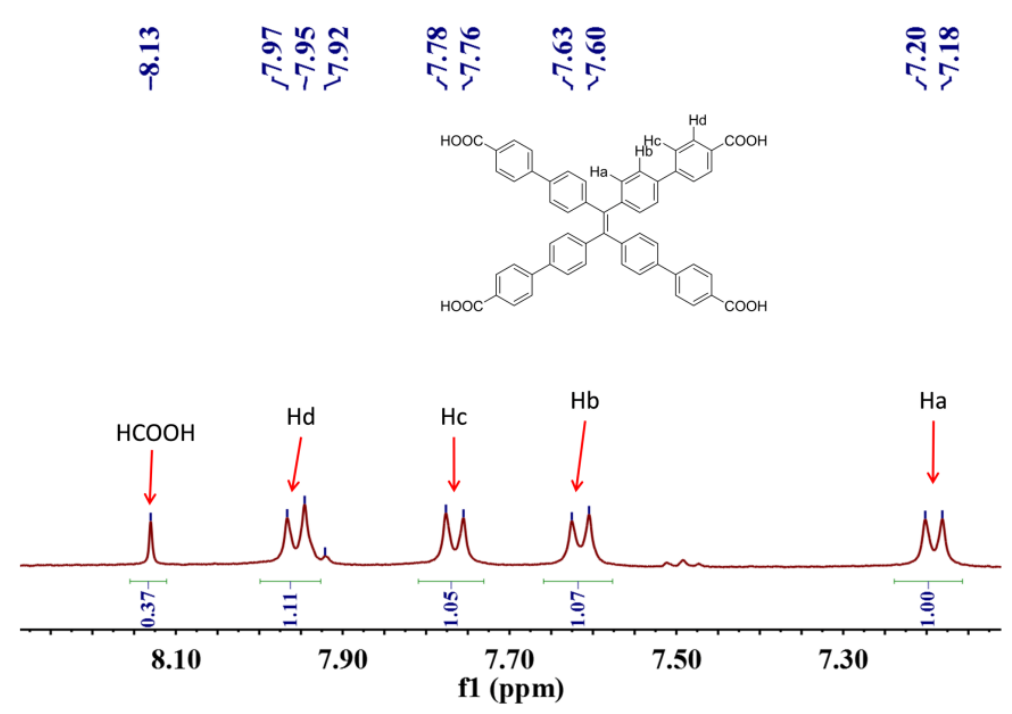

Figure S1. The ${ }^{1} \mathrm{H}$ NMR spectroscopy of digested LIFM-114 (HCOOH : $\mathrm{H}_{4} \mathrm{ETTC}=$ $3.0: 1)$.

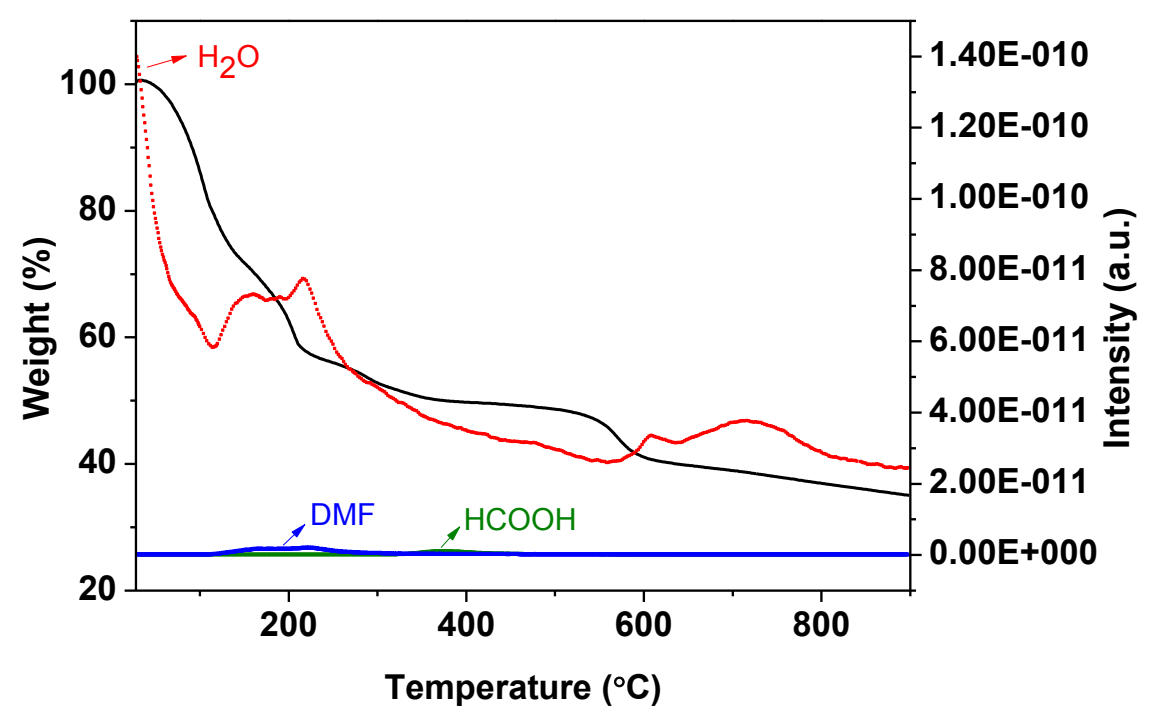

Figure S2. The thermogravimetric (TG)- mass spectrum (MS) analysis of LIFM-114.

Notes: Heating the sample from 25 to $100{ }^{\circ} \mathrm{C}$, the free water molecules in the framework are escaped, corresponding to approx. $20 \%$ weight loss. In this temperature range, the MOF structure behaves reversible "breathing effect", and PL tuning can be executed by multiplexing approaches. From 100 to $200{ }^{\circ} \mathrm{C}$, the free DMF and coordinated water molecules are escaped, accounting for another $20 \%$ weight loss. 


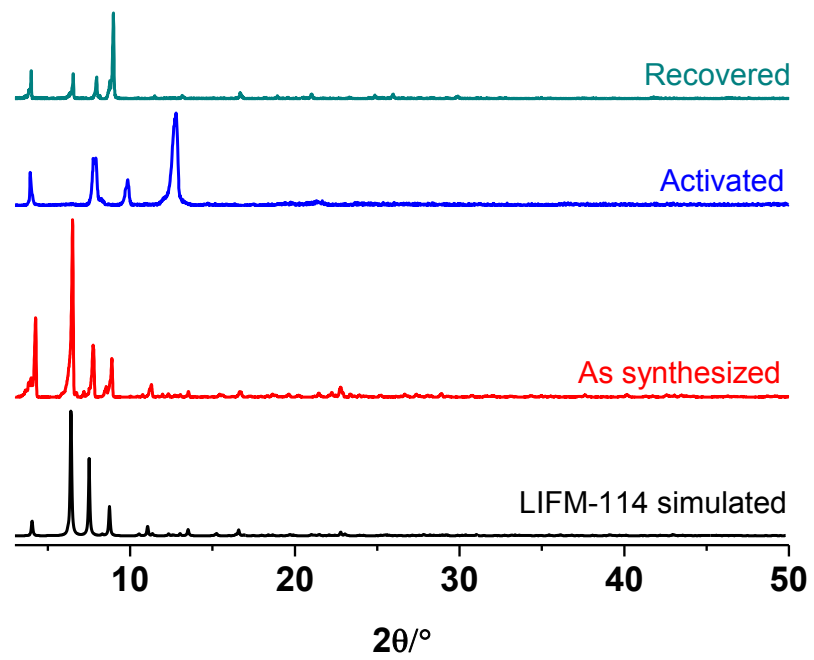

Figure S3. The PXRD patterns of LIFM-114.

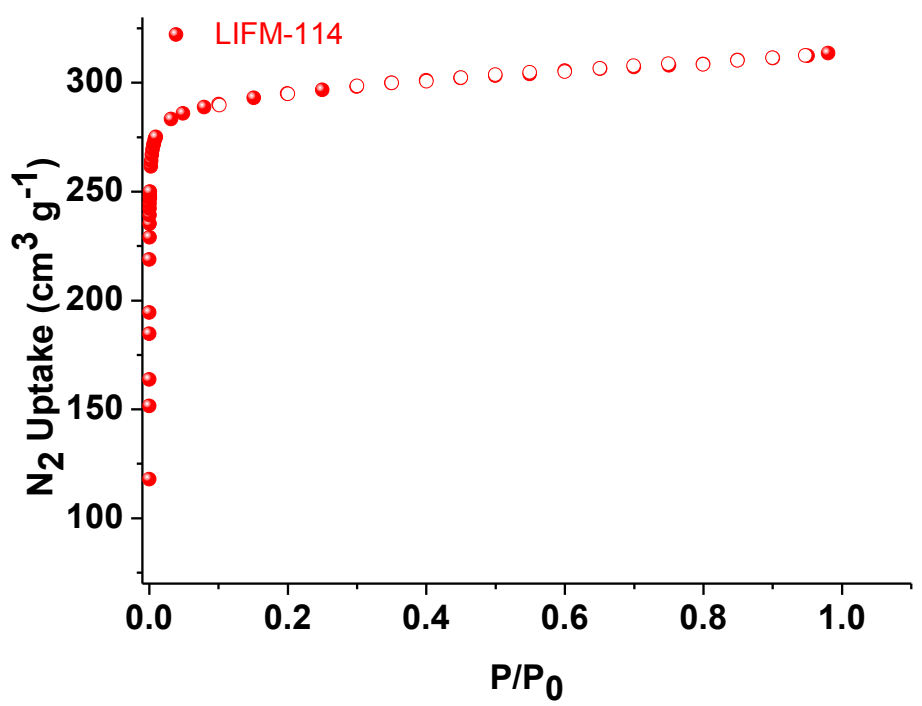

Figure S4. The $\mathrm{N}_{2}$ sorption isotherm of LIFM-114 at $77 \mathrm{~K}$. 


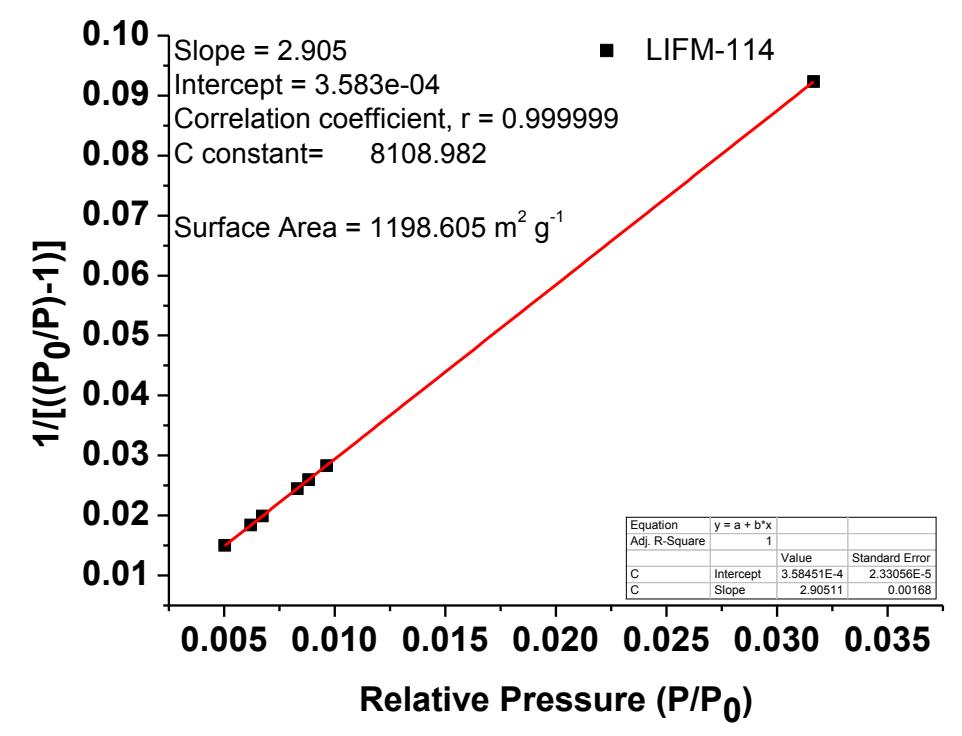

Figure S5. Plot of the linear region on $\mathrm{N}_{2}$ isotherm of LIFM-114 for BET equation.



Figure S6. Pore size distribution of LIFM-114 calculated by SF analysis.

Table S3 Porosity parameters of LIFM-114.

\begin{tabular}{cccc}
\hline Structure & $\mathrm{S}_{\mathrm{BET}}\left(\mathrm{m}^{2} / \mathrm{g}\right)$ & $\begin{array}{c}\text { Total Pore Volume } \\
(\mathrm{cc} / \mathrm{g})\end{array}$ & $\begin{array}{c}\text { Pore Size by SF } \\
(\AA)\end{array}$ \\
\hline LIFM-114 & 1198 & 0.49 & 10.2 \\
\hline
\end{tabular}






Figure S7. The PXRD patterns of LIFM-114 immersed in aqueous solution with different $\mathrm{pH}$ values for $48 \mathrm{~h}$.

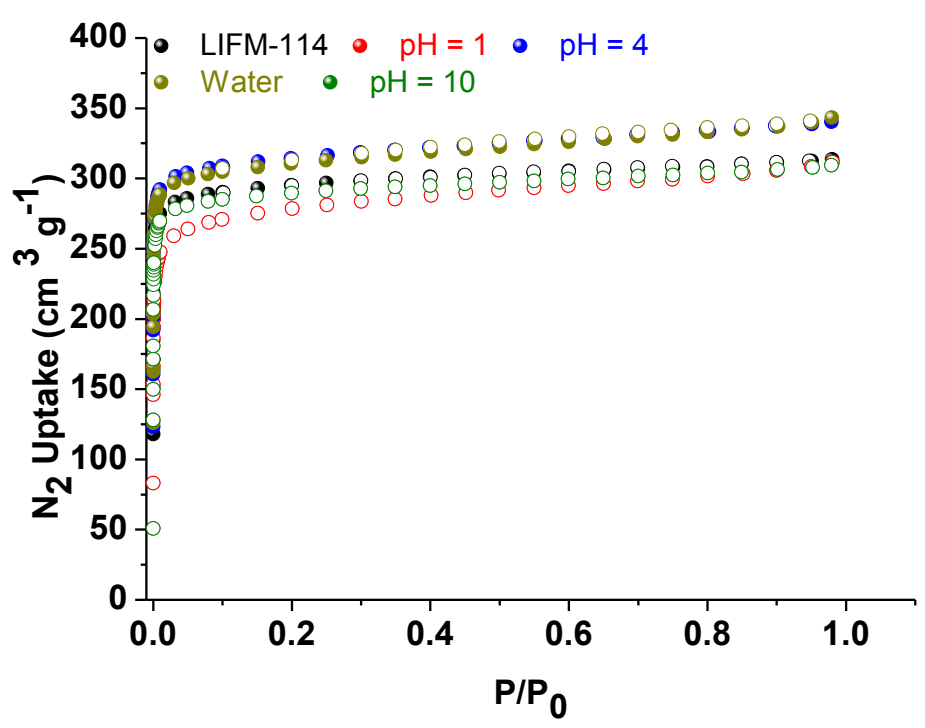

Figure S8. $\mathrm{N}_{2}$ sorption isotherm at $298 \mathrm{~K}$ for LIFM-114 samples after treatment in aqueous solution with different $\mathrm{pH}$ values for $48 \mathrm{~h}$. Solid symbols: adsorption; open symbols: desorption. 

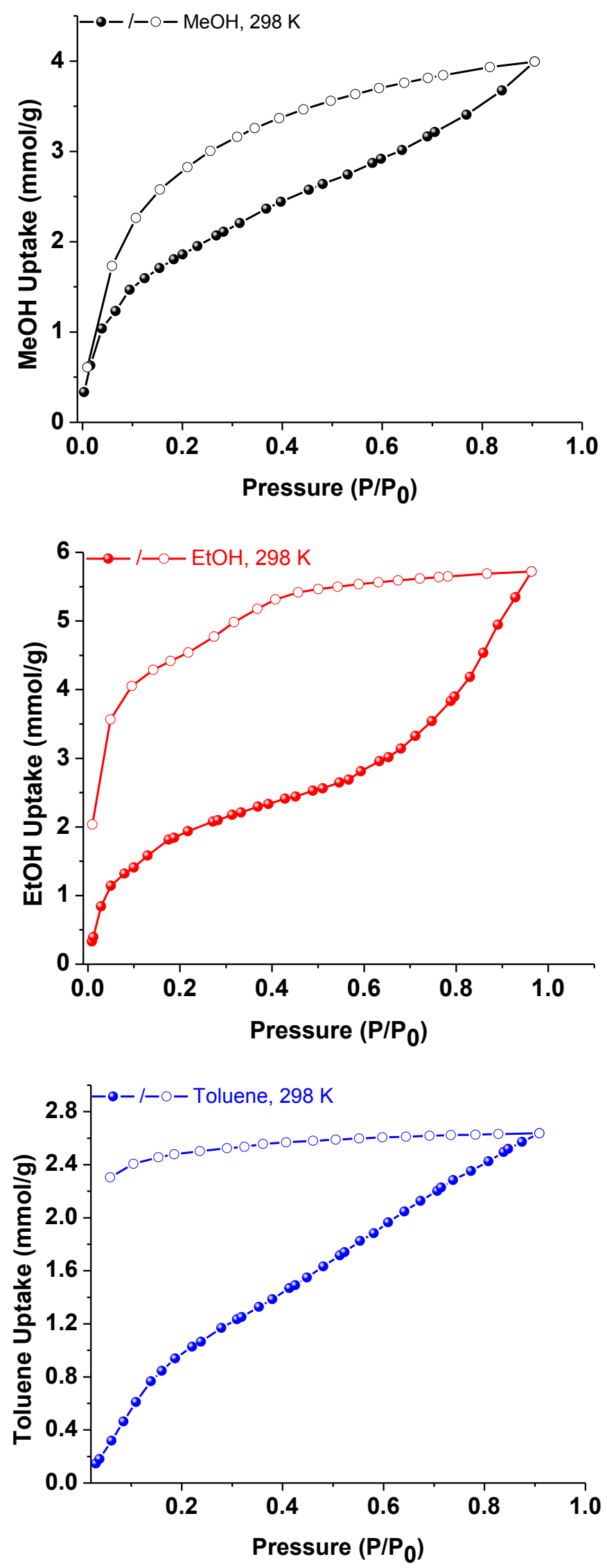

Figure S9. MeOH, EtOH and toluene sorption isotherms of LIFM-114 at $298 \mathrm{~K}$. 


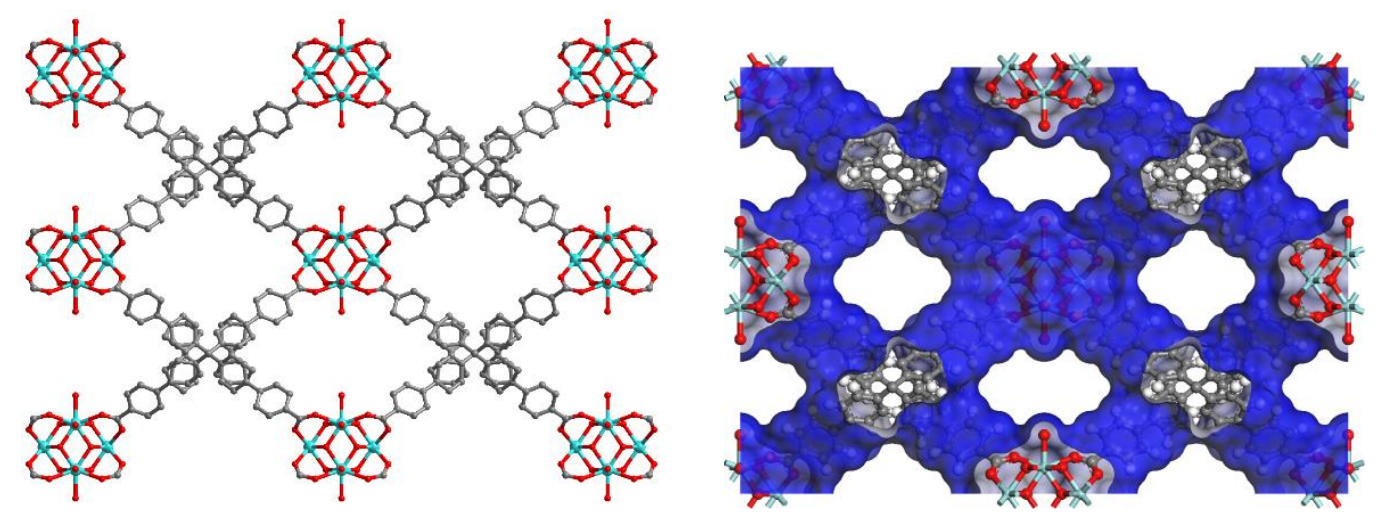

LIFM-114
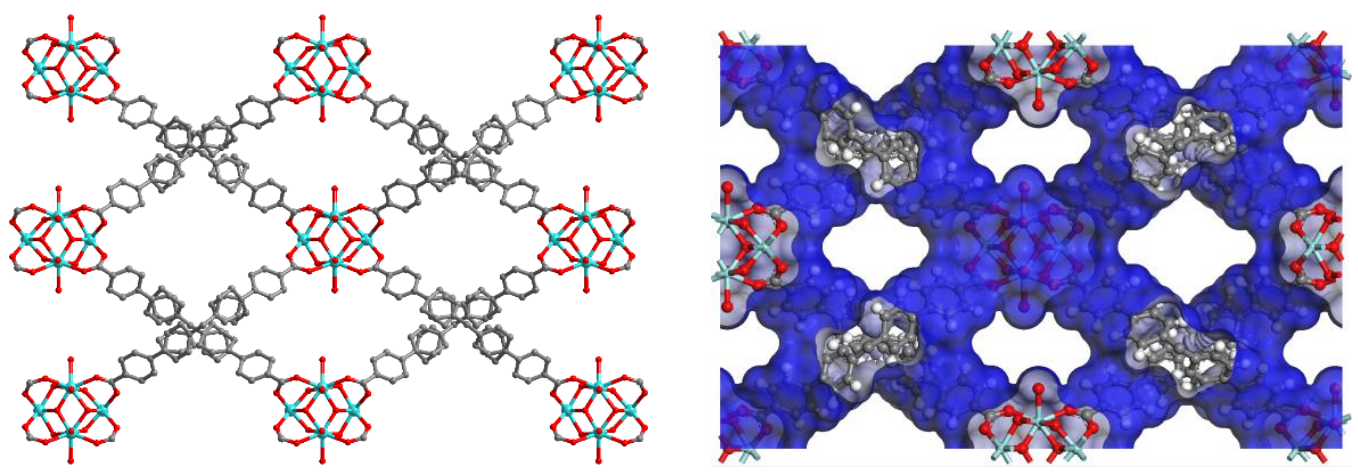

LIFM-114-Toluene

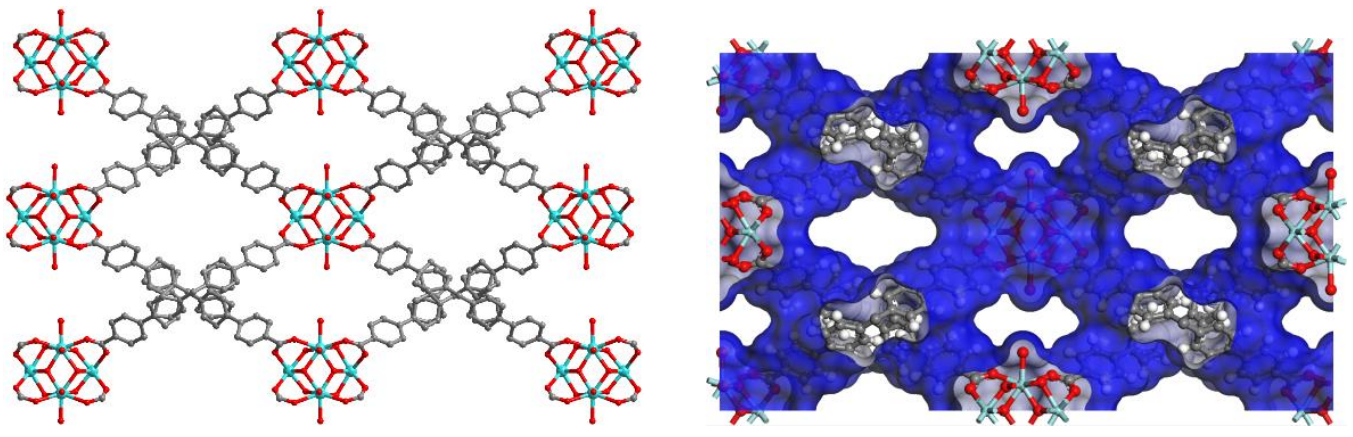

LIFM-114-EtOH 
340

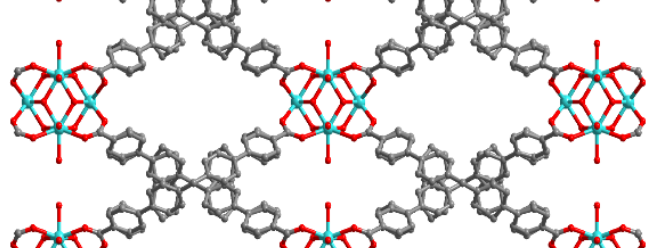
30050

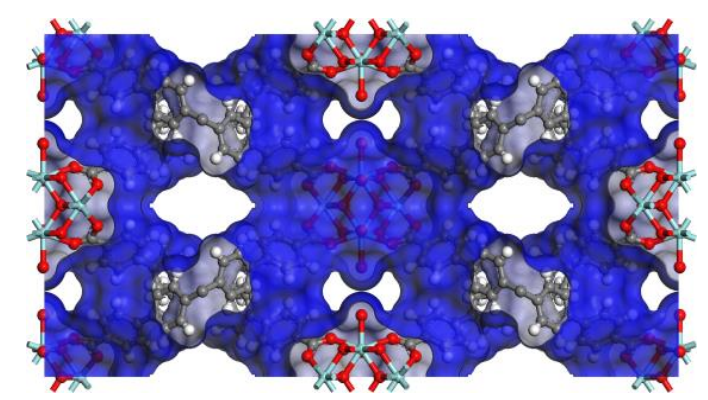

LIFM-114-MeOH

250 38 32

LIFM-114-DCM

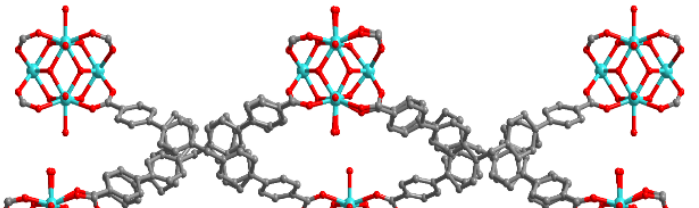
30.

LIFM-114-Et $2 \mathrm{O}$
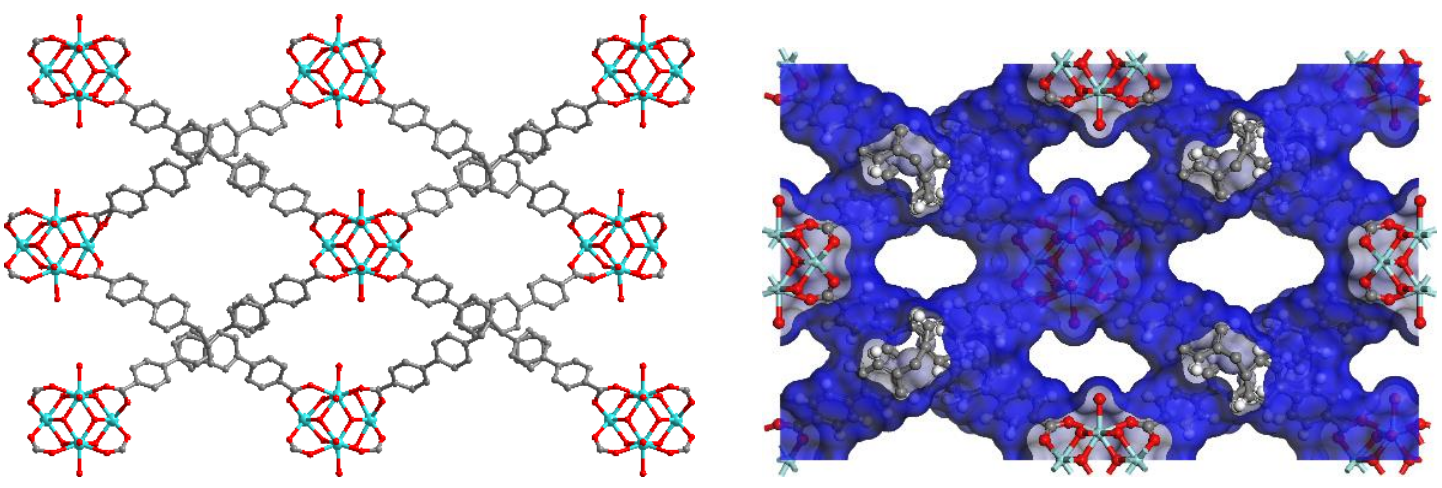

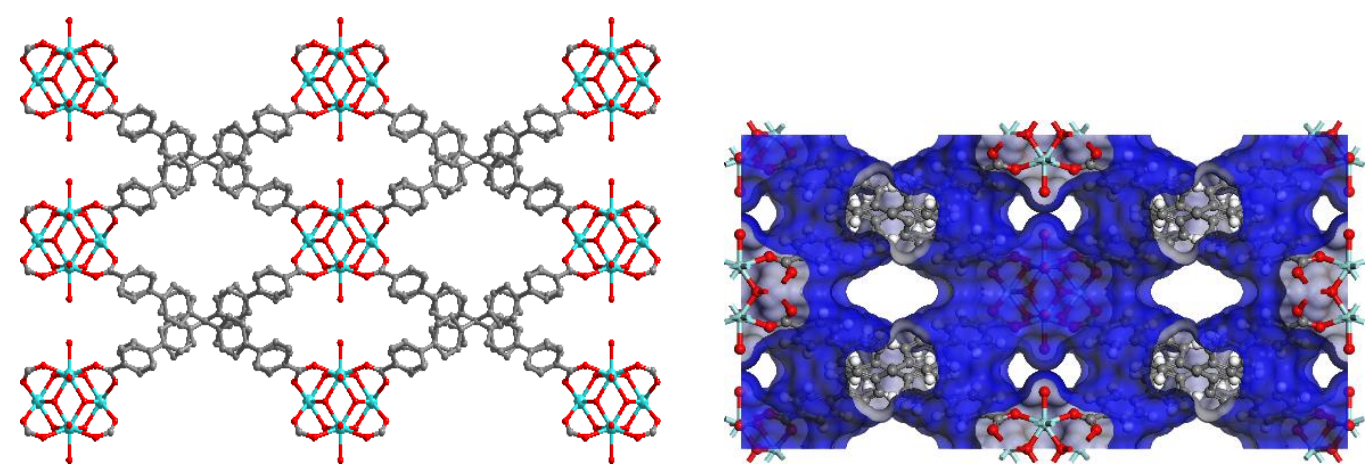

LIFM- $114-60^{\circ} \mathrm{C}$
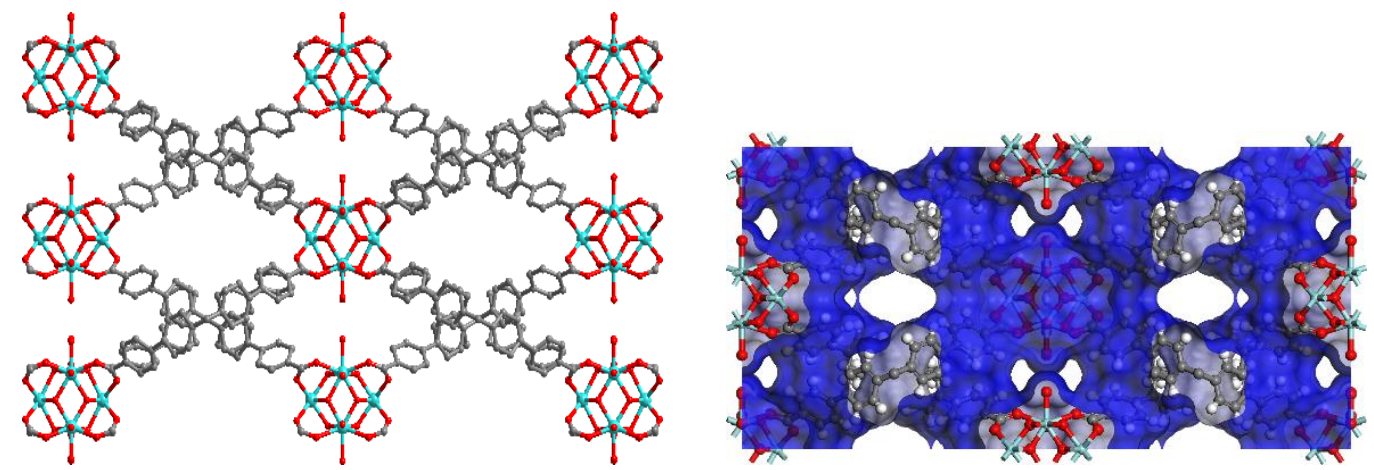

LIFM- $114-80^{\circ} \mathrm{C}$

Figure S10. The crystal structures of LIFM-114, LIFM-114-Toluene, LIFM-114EtOH, LIFM-114-MeOH, LIFM-114-DCM, LIFM-114-Et 2 O, LIFM-114-40 ${ }^{\circ}$, LIFM-114- $60^{\circ} \mathrm{C}$, LIFM- $114-80^{\circ} \mathrm{C}$ showing different pores along $a$-axis. 


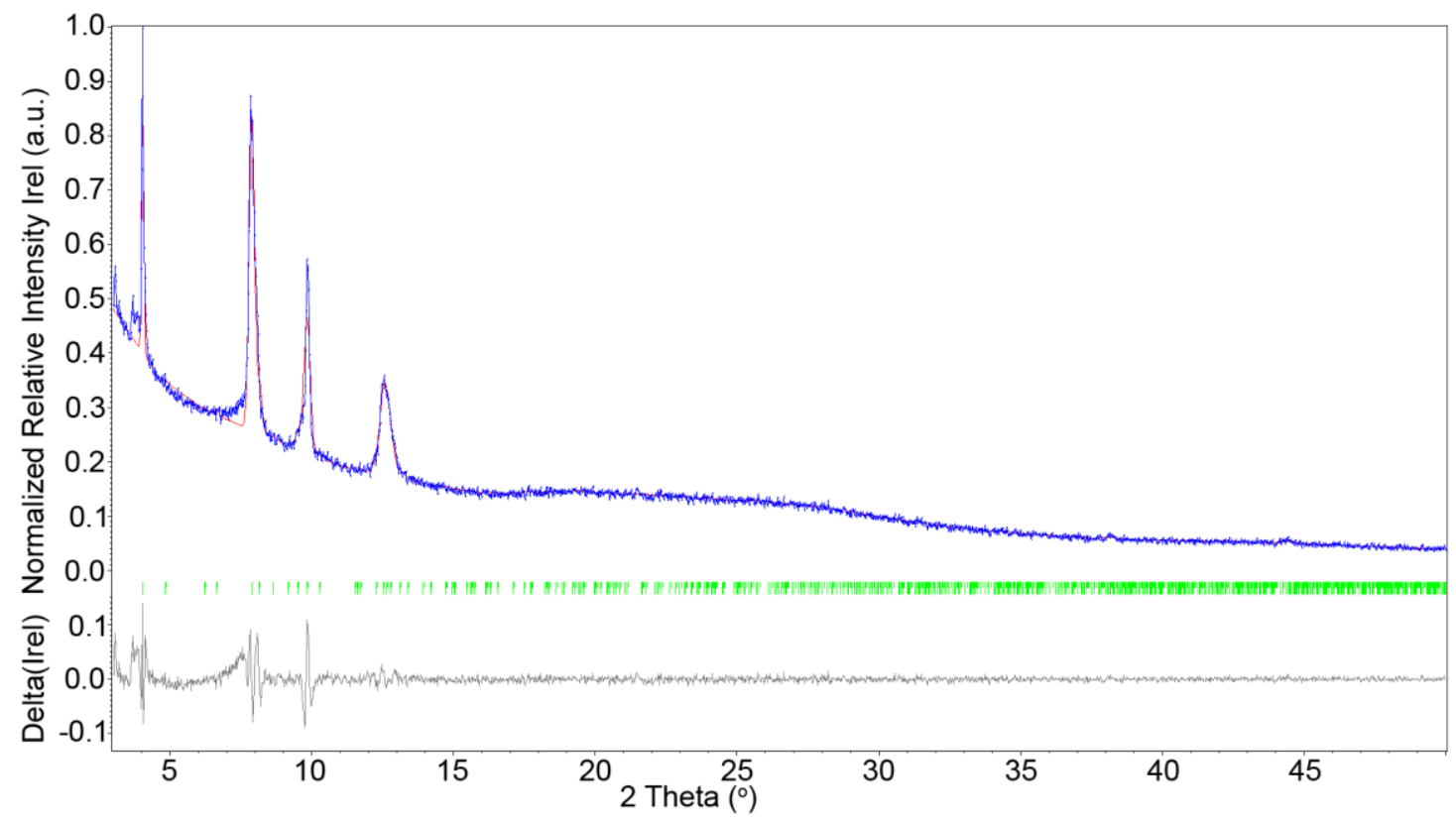

Figure S11. Observed (black), calculated (red) and difference (grey) PXRD patterns for the Le Bail refinement of LIFM-114cp. The green vertical bars correspond to the positions of Bragg peaks.

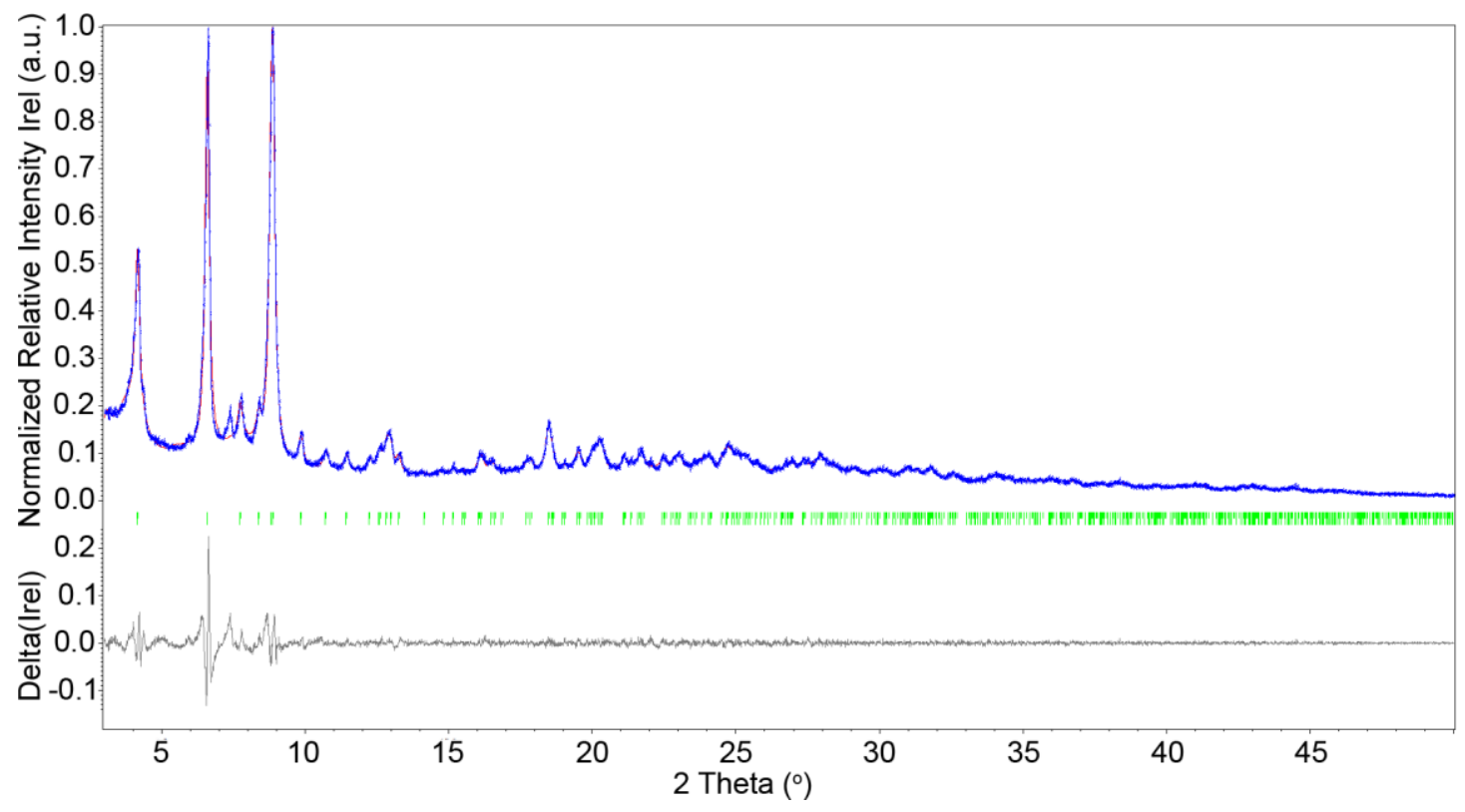

Figure S12. Observed (black), calculated (red) and difference (grey) PXRD patterns for the Le Bail refinement of LIFM-114-8MPa. The green vertical bars correspond to the positions of Bragg peaks. 




Figure S13. Observed (black), calculated (red) and difference (grey) PXRD patterns for the Le Bail refinement of LIFM-114-12MPa. The green vertical bars correspond to the positions of Bragg peaks.

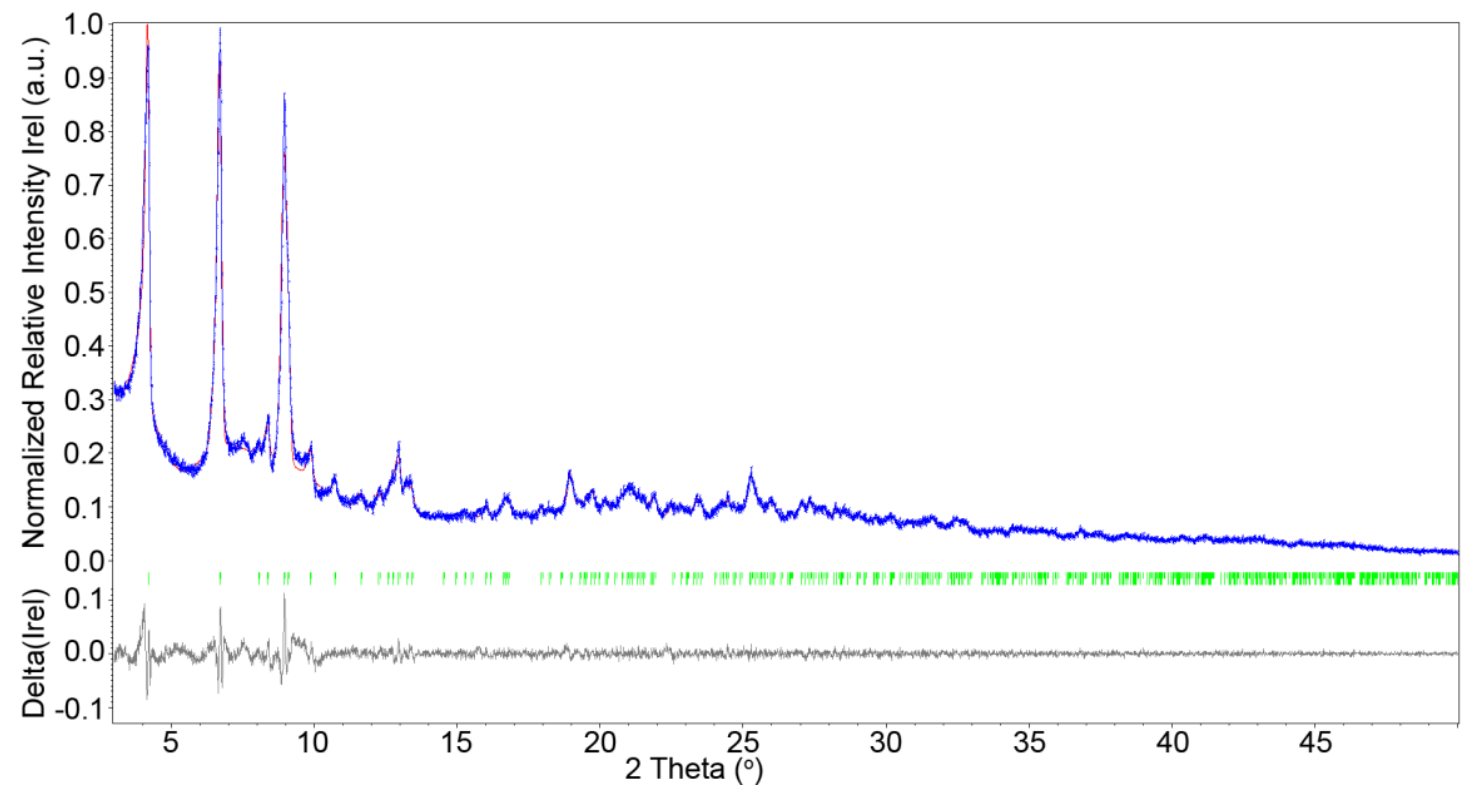

Figure S14. Observed (black), calculated (red) and difference (grey) PXRD patterns for the Le Bail refinement of LIFM-114-16MPa. The green vertical bars correspond to the positions of Bragg peaks. 


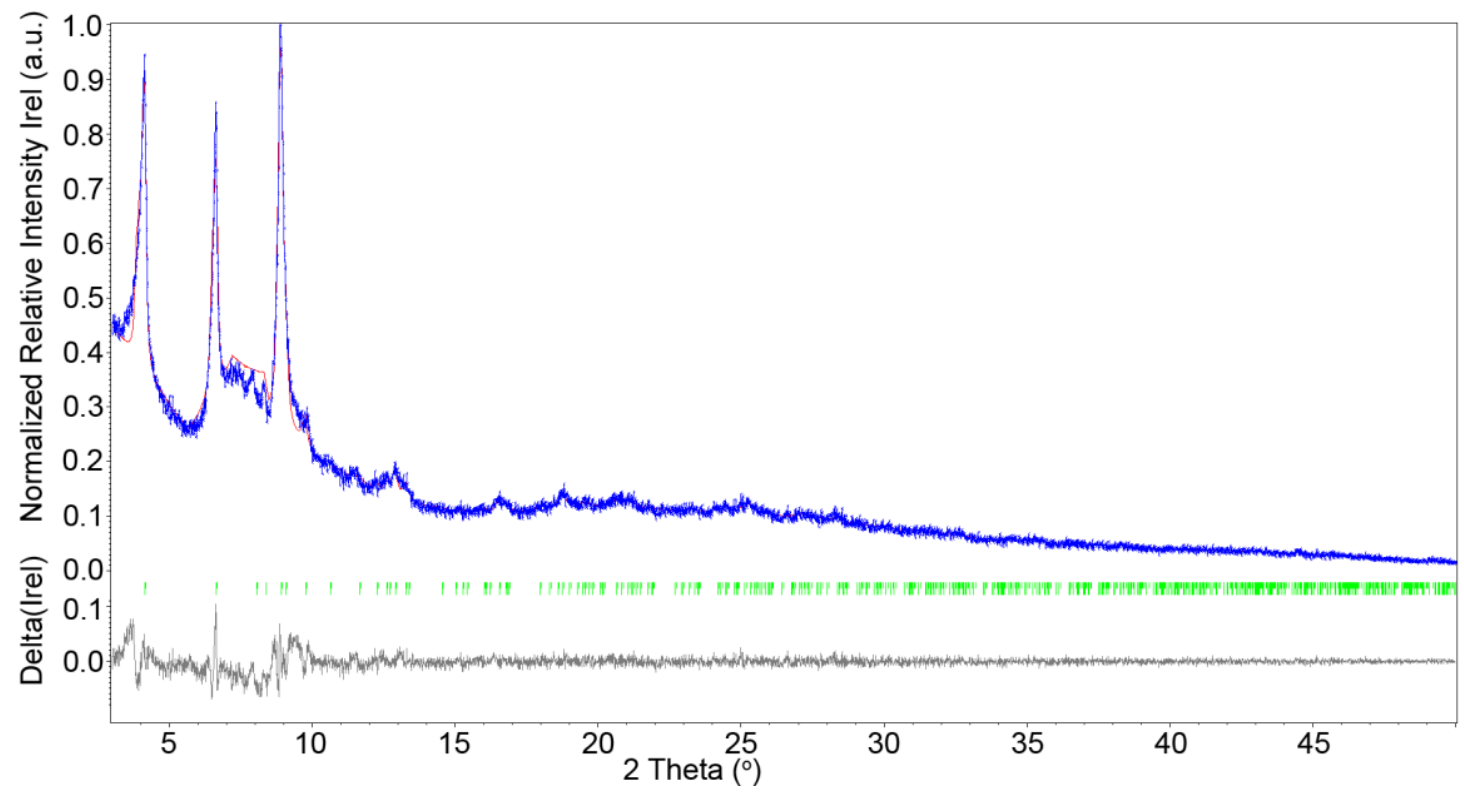

Figure S15. Observed (black), calculated (red) and difference (grey) PXRD patterns for the Le Bail refinement of LIFM-114-20MPa. The green vertical bars correspond to the positions of Bragg peaks.



Figure S16. The PXRD patterns of LIFM-114, LIFM-114-100 ${ }^{\circ}$, LIFM-114-cp, and LIFM-114-recovered. 




Figure S17. The PXRD patterns of LIFM-114-40 ${ }^{\circ} \mathrm{C}$ (black, simulated, red, tested).



Figure S18. The PXRD patterns of LIFM-114- $60{ }^{\circ} \mathrm{C}$ (black, simulated, red, tested). 


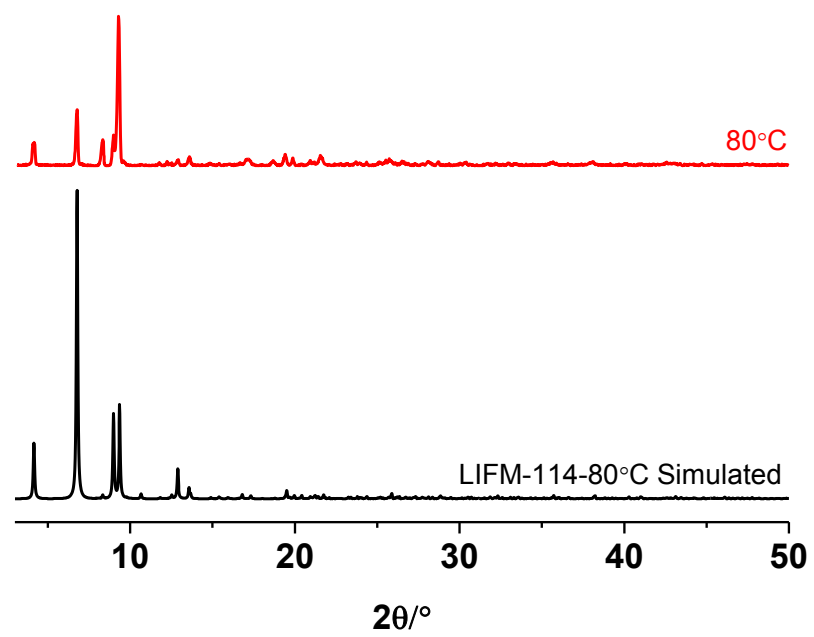

Figure S19. The PXRD patterns of LIFM-114-80 ${ }^{\circ} \mathrm{C}$ (black, simulated, red, tested).
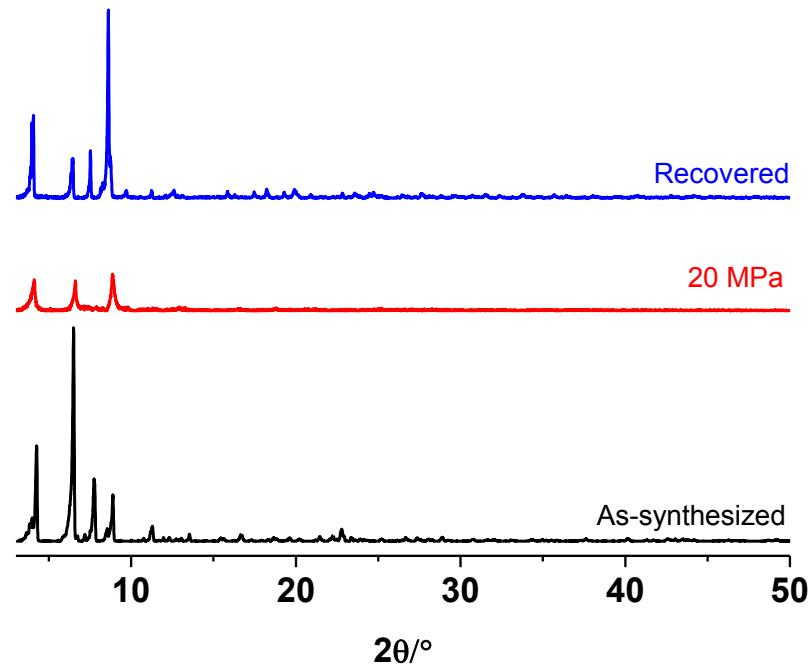

Figure S20. PXRD patterns of as-synthesized LIFM-114, LIFM-114-20MPa and recovered LIFM-114. 




Figure S21. PXRD patterns of LIFM-114 with different pressure load.

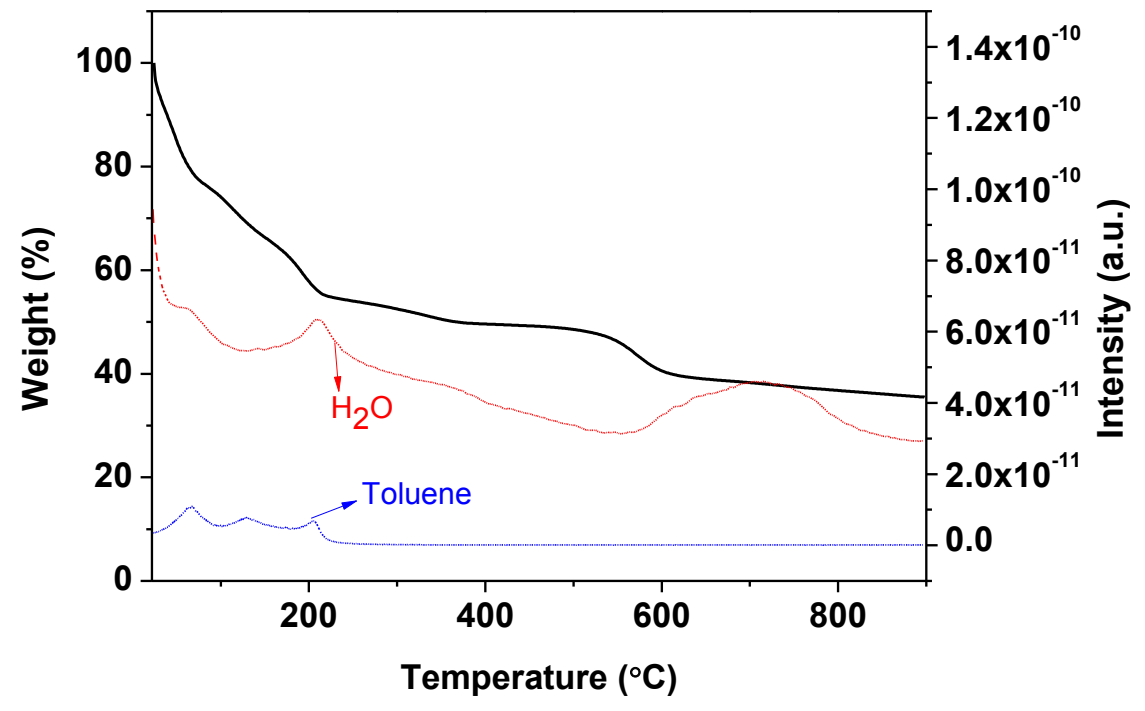

Figure S22. The TG-MS analysis of LIFM-114-Toluene. 


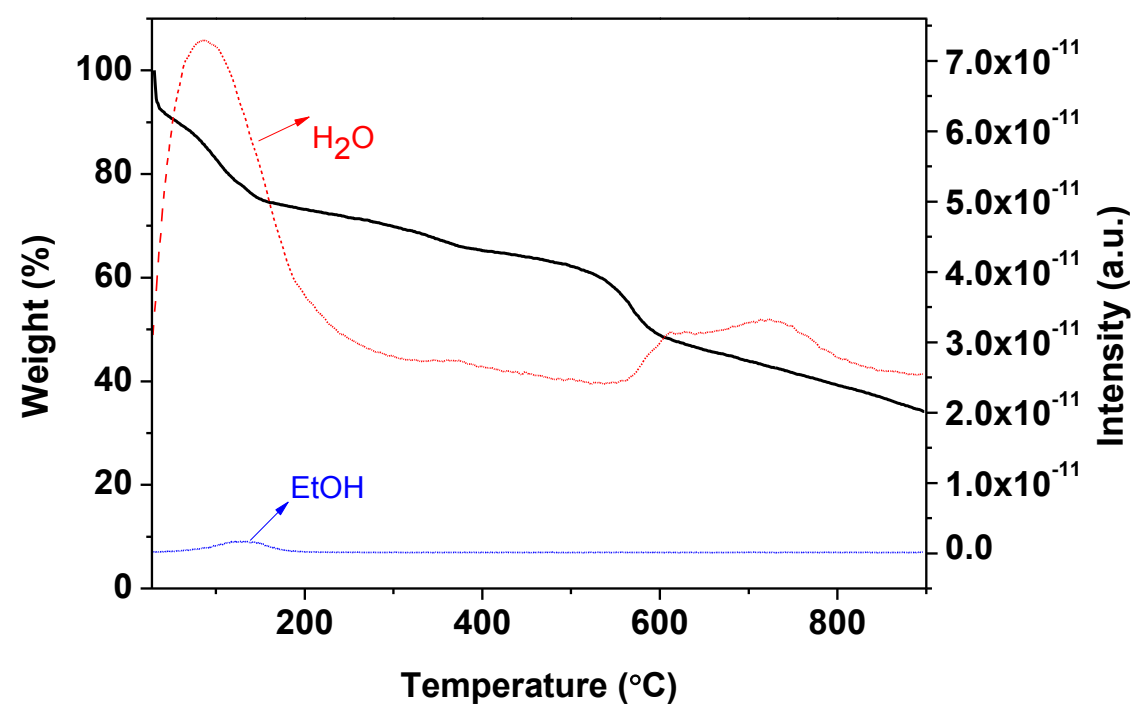

Figure S23. The TG-MS analysis of LIFM-114-EtOH.



Figure S24. The TG-MS analysis of LIFM-114-MeOH. 


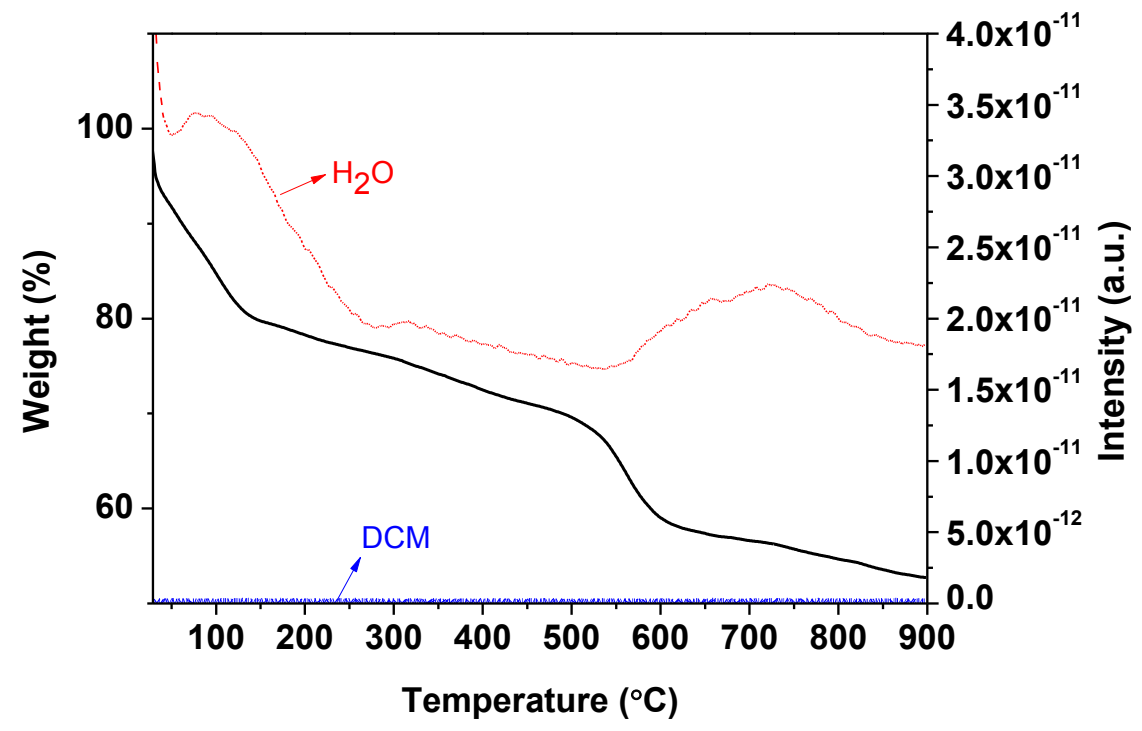

Figure S25. The TG-MS analysis of LIFM-114-DCM.

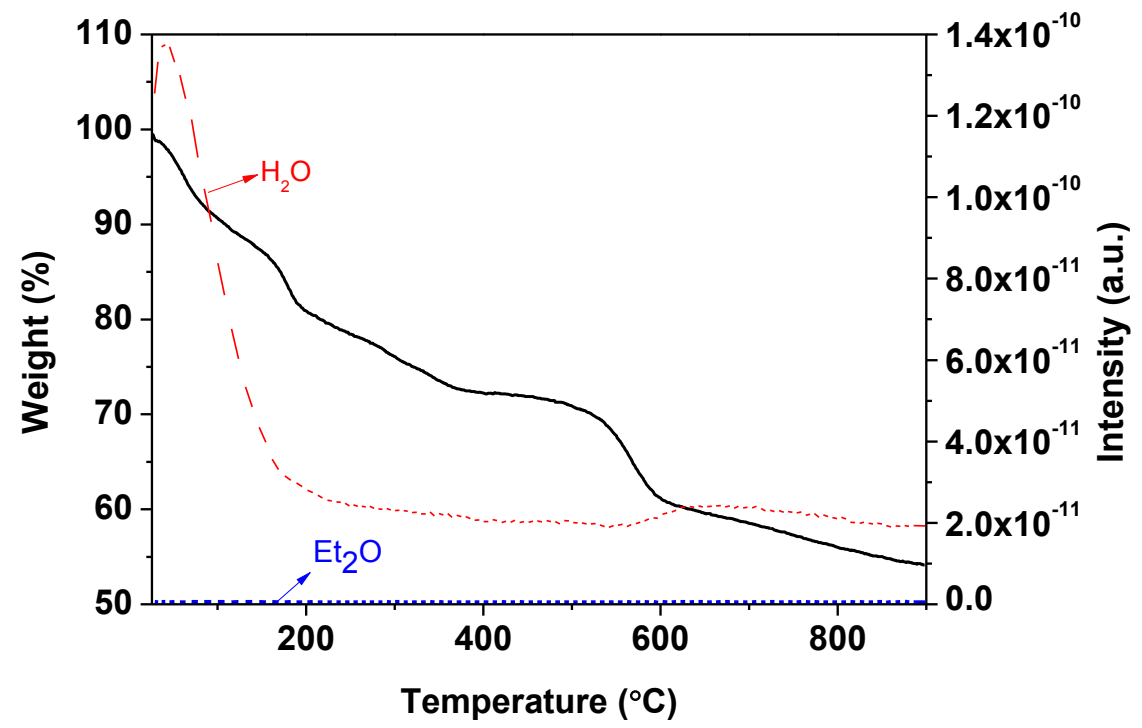

Figure S26. The TG-MS analysis of LIFM-114- $\mathrm{Et}_{2} \mathrm{O}$. 


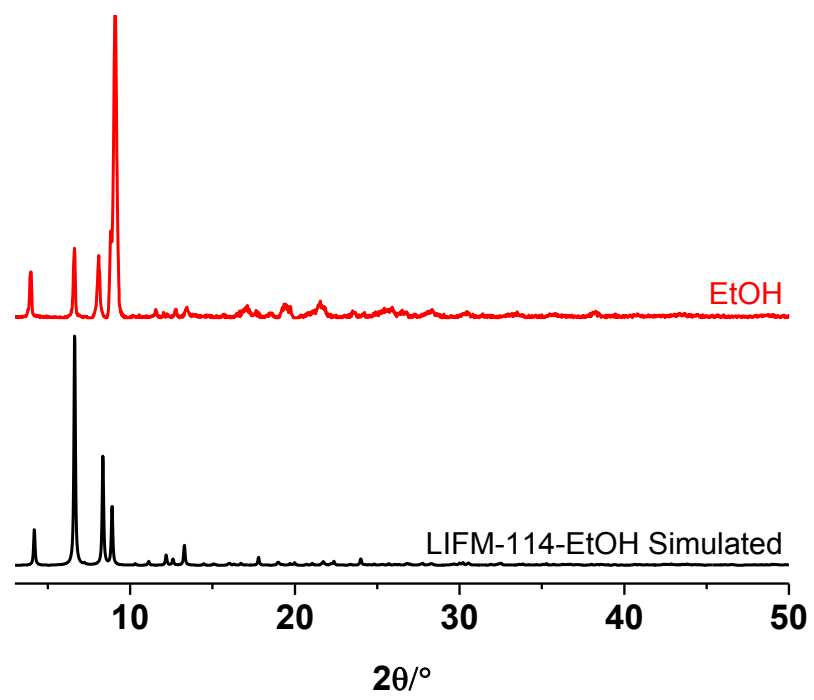

Figure S27. The PXRD patterns of LIFM-114-EtOH (black, simulated, red, tested).

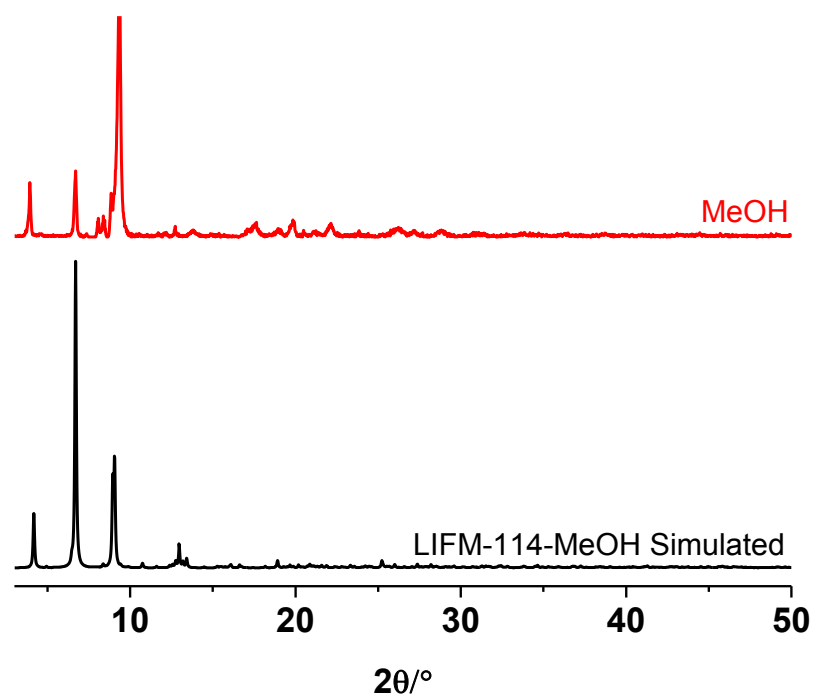

Figure S28. The PXRD patterns of LIFM-114-MeOH (black, simulated, red, tested).

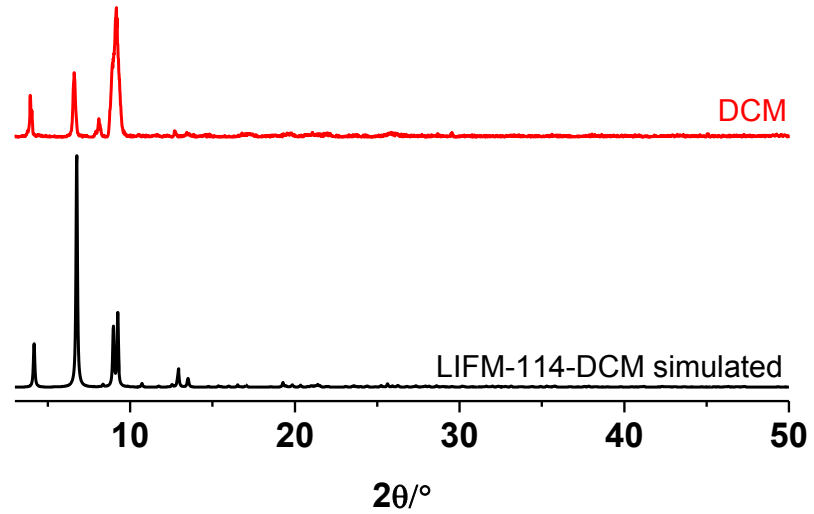

Figure S29. The PXRD patterns of LIFM-114-DCM (black, simulated, red, tested). 


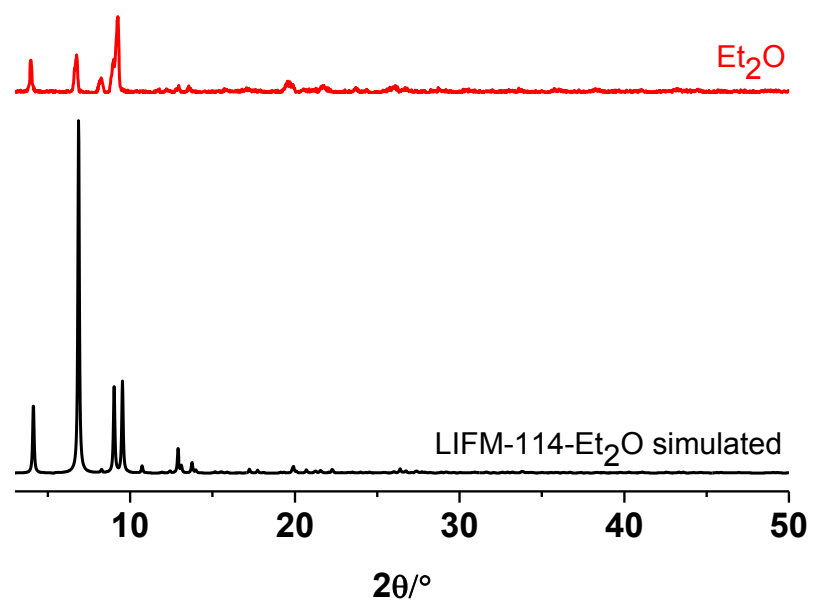

Figure S30. The PXRD patterns of LIFM-114-Et ${ }_{2} \mathrm{O}$ (black, simulated, red, tested).

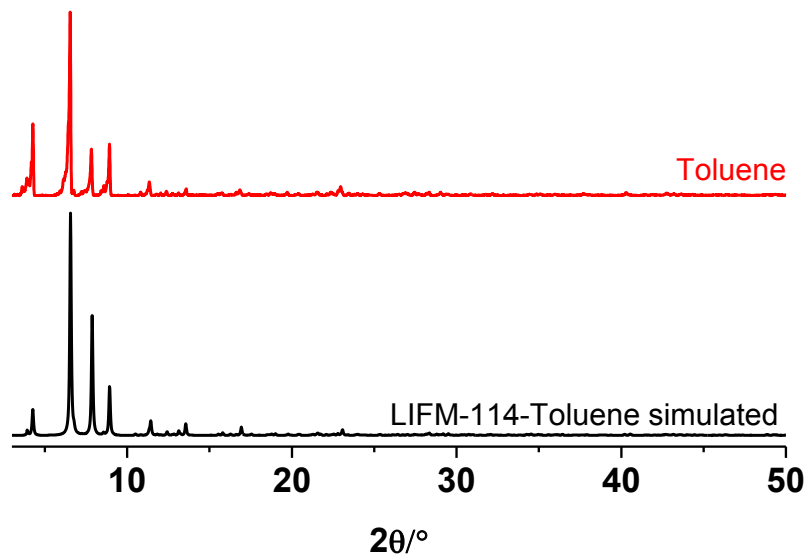

Figure S31. The PXRD patterns of LIFM-114-Toluene (black, simulated, red, tested).

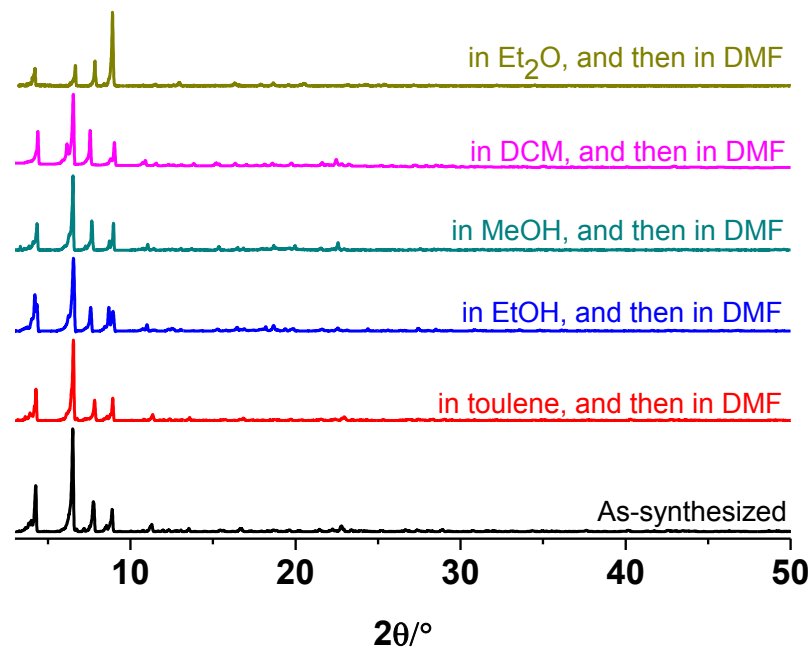

Figure S32. The PXRD patterns of LIFM-114 immersed in different organic solvents for $24 \mathrm{~h}$, and then immersed in DMF for $24 \mathrm{~h}$ at room temperature. 


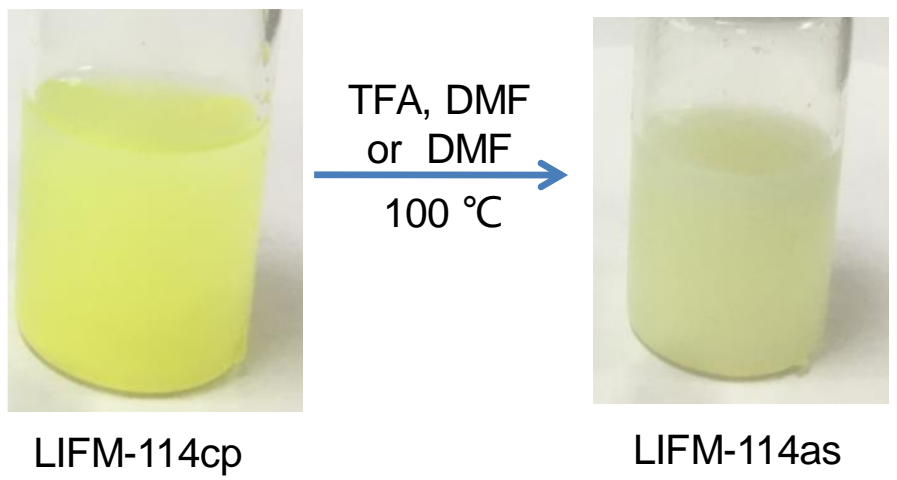

Figure S33. The color change of LIFM-114cp from yellow to light white after the treatment with TFA in DMF under heating, suggesting recovery of LIFM-114.

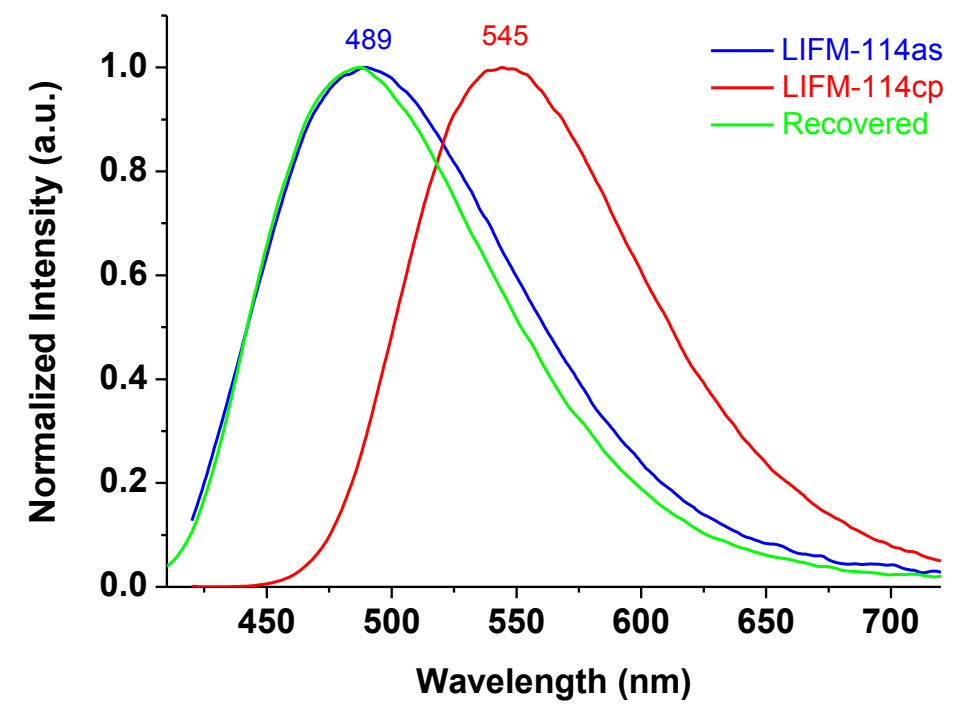

Figure S34. The emission spectra of LIFM-114 (blue), LIFM-114cp (red) and recovered LIFM-114 (green, $\lambda_{\mathrm{Ex}}=398 \mathrm{~nm}$ ). 




$$
\begin{aligned}
& \underset{\text { TFA, DMF }}{\text { or DMF }} \\
& \underset{100{ }^{\circ} \mathrm{C}}{\longrightarrow}
\end{aligned}
$$

Figure S35. The color change of LIFM-114-20MPa from yellow to light white after the treatment with TFA in DMF under heating, suggesting recovery of LIFM-114.

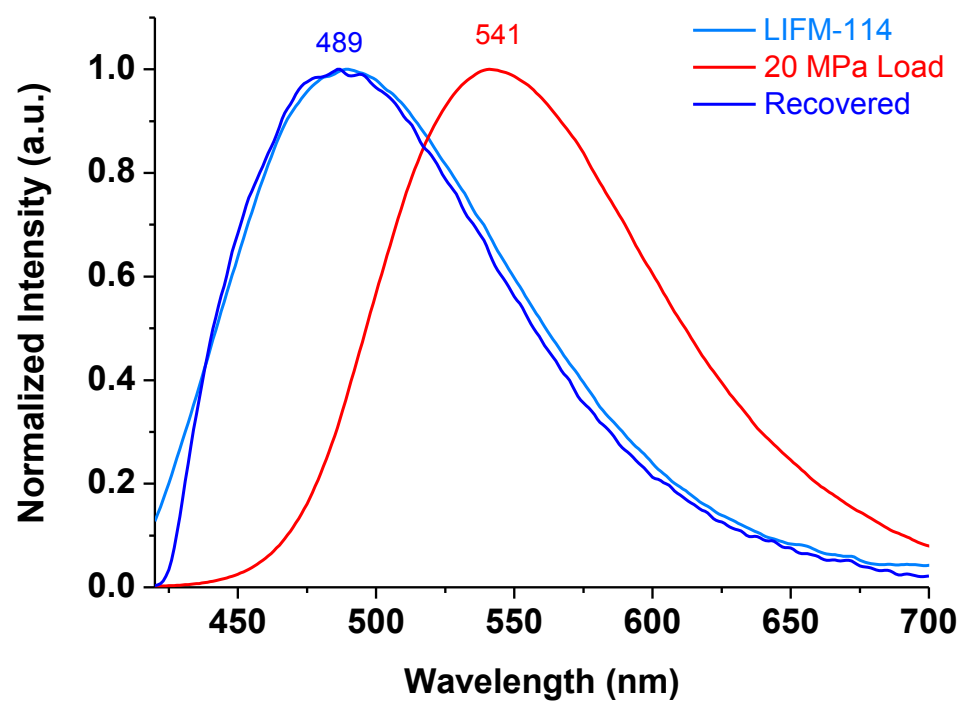

Figure S36. The emission spectra of LIFM-114, LIFM-114-20MPa and recovered LIFM-114 $\left(\lambda_{\mathrm{Ex}}=398 \mathrm{~nm}\right)$. 

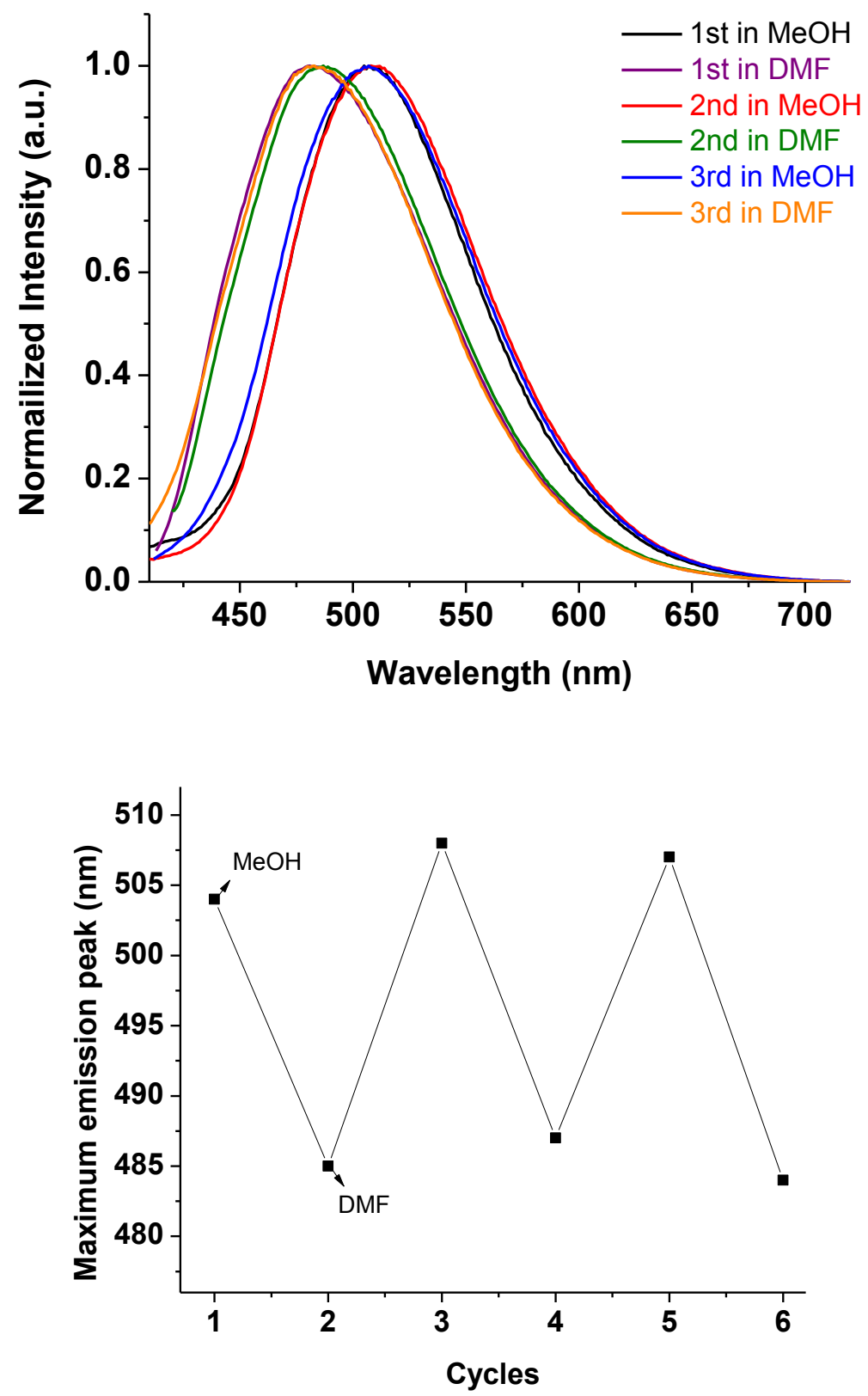

Figure S37. The fluorescence reversible cycles between LIFM-114-MeOH and LIFM$114\left(\lambda_{\mathrm{Ex}}=398 \mathrm{~nm}\right)$. 


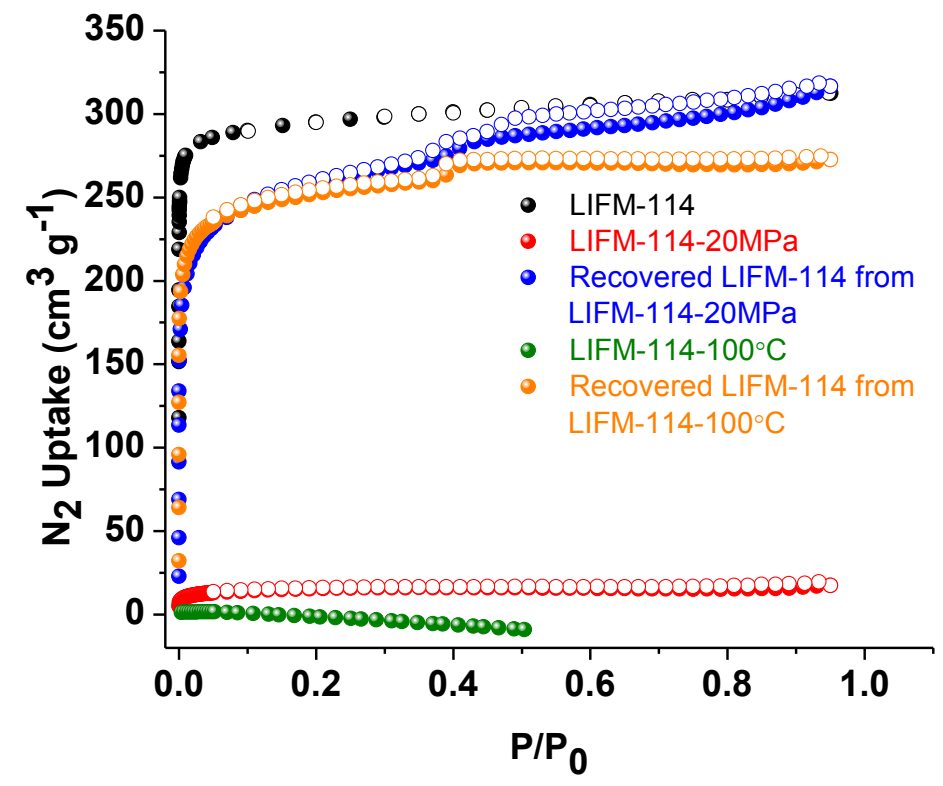

Figure S38. The $\mathrm{N}_{2}$ adsorption isotherms of LIFM-114, LIFM-114-20MPa, recovered LIFM-114 from LIFM-114-20MPa, LIFM-114-100 ${ }^{\circ} \mathrm{C}$ and recovered LIFM-114 from LIFM-114- $100^{\circ} \mathrm{C}$.

Table S4. The porosity parameters of LIFM-114, recovered LIFM-114 from LIFM114-20MPa and recovered LIFM-114 from LIFM-114-100 ${ }^{\circ} \mathrm{C}$.

\begin{tabular}{|c|c|c|}
\hline structure & $\mathrm{S}_{\mathrm{BET}}\left(\mathrm{m}^{2} \mathrm{~g}^{-1}\right)$ & Total Pore Volume $(\mathrm{cc} / \mathrm{g})$ \\
\hline LIFM-114 & 1198 & 0.49 \\
\hline $\begin{array}{c}\text { Recovered LIFM-114 from } \\
\text { LIFM-114-20MPa }\end{array}$ & 961 & 0.49 \\
\hline $\begin{array}{c}\text { Recovered LIFM-114 from } \\
\text { LIFM-114-110 } \mathrm{C}\end{array}$ & 959 & 0.42 \\
\hline
\end{tabular}



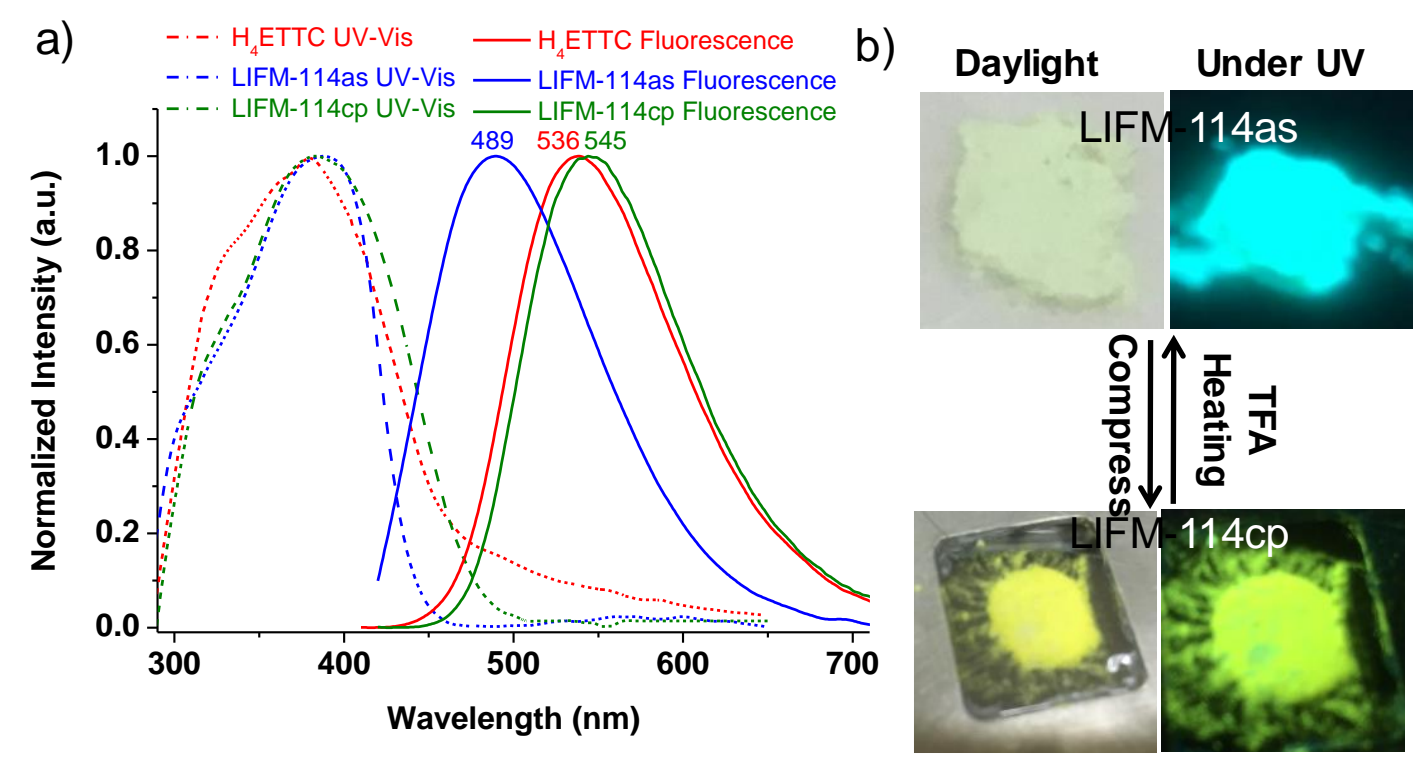

Figure S39. (a) Diffuse reflectance spectra of $\mathrm{H}_{4}$ ETTC (dashed red line), LIFM-114 (dashed blue line), and LIFM-114cp (dashed green line) and fluorescent spectra of $\mathrm{H}_{4}$ ETTC (solid red line), LIFM-114 (solid blue line), and LIFM-114cp (solid green line) at room temperature. (b) Photos showing the color of LIFM-114 and LIFM-114cp under room light and under UV light.

Table S5 The absolute quantum yields $\left(\lambda_{\mathrm{ex}}=398 \mathrm{~nm}\right)$ and decay lifetimes.

\begin{tabular}{|c|c|c|}
\hline Sample & Quantum yield (\%) & Decay lifetime (ns) \\
\hline $\mathrm{H}_{4} \mathrm{ETTC}$ & 48.9 & 3.83 \\
\hline $\mathrm{H}_{4}$ ETTC grind & 65.6 & 2.55 \\
\hline LIFM-114 & 61.3 & 4.02 \\
\hline LIFM-114cp & 77.1 & 4.00 \\
\hline LIFM-114-20MPa & 68.0 & 2.52 \\
\hline LIFM-114-25 ${ }^{\circ} \mathrm{C}$ & $/$ & 3.82 \\
\hline LIFM-114-100 ${ }^{\circ} \mathrm{C}$ & $/$ & 2.55 \\
\hline LIFM-114-Toluene & $/$ & 2.90 \\
\hline LIFM-114-Et ${ }_{2} \mathrm{O}$ & $/$ & \\
\hline
\end{tabular}




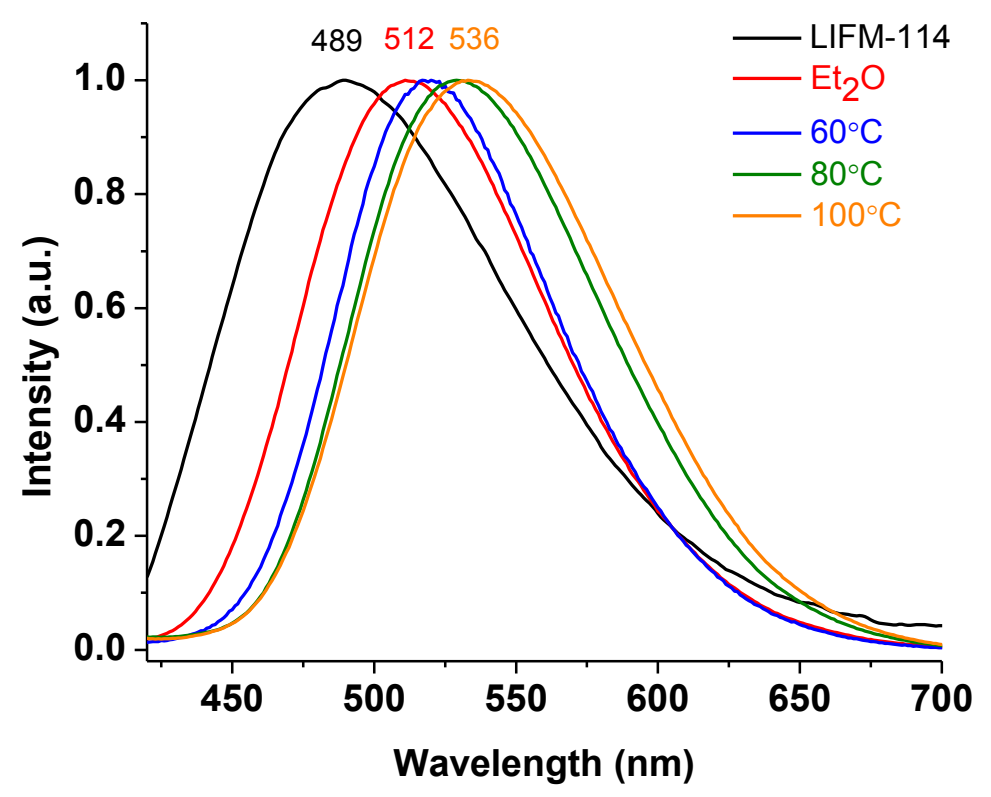

Figure S40. The emission spectra of LIFM-114- $\mathrm{Et}_{2} \mathrm{O}$ and treated with different temperature $\left(\lambda_{\mathrm{Ex}}=398 \mathrm{~nm}\right)$.

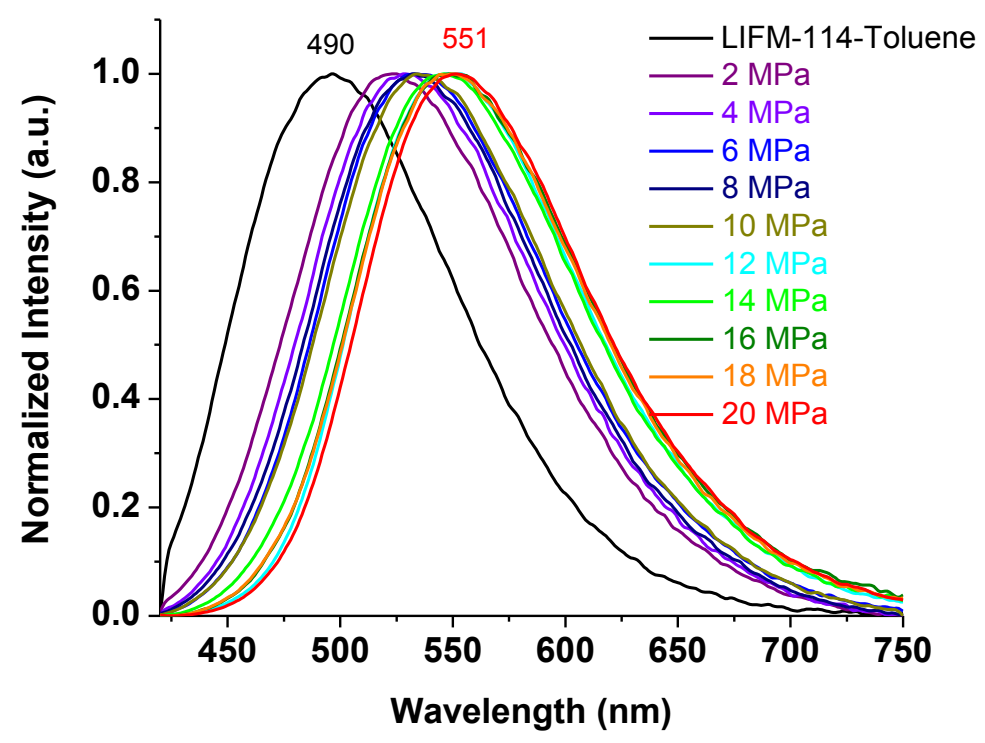

Figure S41. The emission spectra of LIFM-114-Toluene and treated under different pressure $(2-20 \mathrm{MPa}, \mathrm{Ex}=398 \mathrm{~nm})$. 


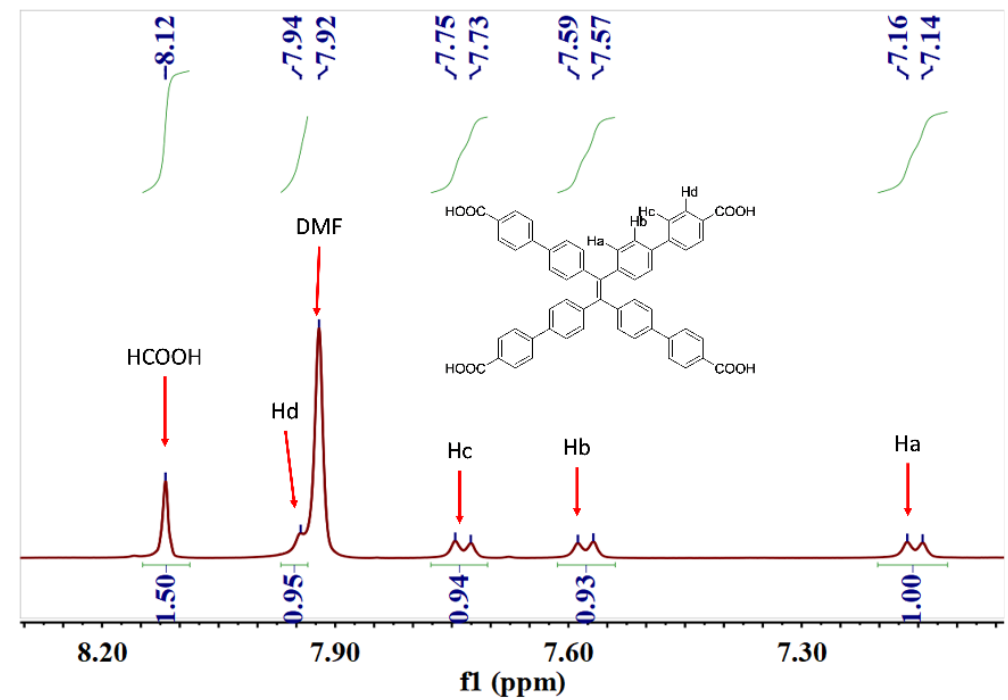

Fig. S42 The ${ }^{1} \mathrm{H}$ NMR spectroscopy of digested LIFM-114 with different amount of formic acid $\left(\mathrm{HCOOH}: \mathrm{H}_{4} \mathrm{ETTC}=12: 1\right)$.

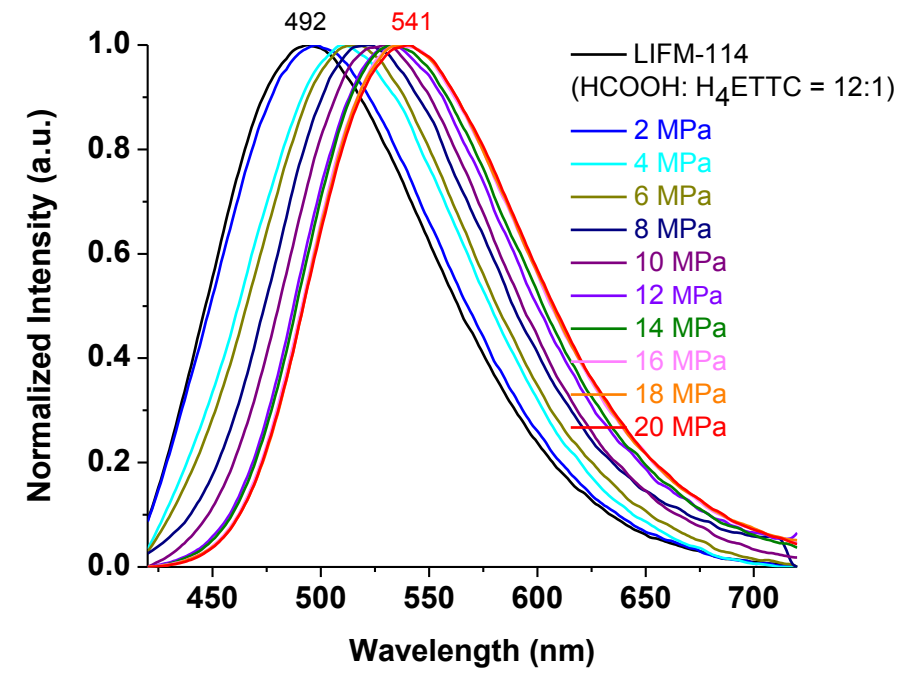

Figure S43. The emission spectra of LIFM-114 with different amount of formic acid $\left(\mathrm{HCOOH}: \mathrm{H}_{4} \mathrm{ETTC}=12: 1\right)$ and treated under different pressure $(2-20 \mathrm{MPa}, \mathrm{Ex}=398$ $\mathrm{nm})$.

Notes: To study the effect of different defect states on the pressure-dependent PL tuning properties of LIFM-114, we prepared a sample with different amount of formic acid, which leads to different density of defect states (Figure S42, in comparison with the ${ }^{1} \mathrm{H}$ NMR spectra of digested LIFM-114 sample as shown in Figure S1). As we can see, its PL response toward pressure is similar with that of LIFM-114 (Figure S43). Hence, we could say the defect state herein is of minor effect on the PL-tuning property of LIFM114. 


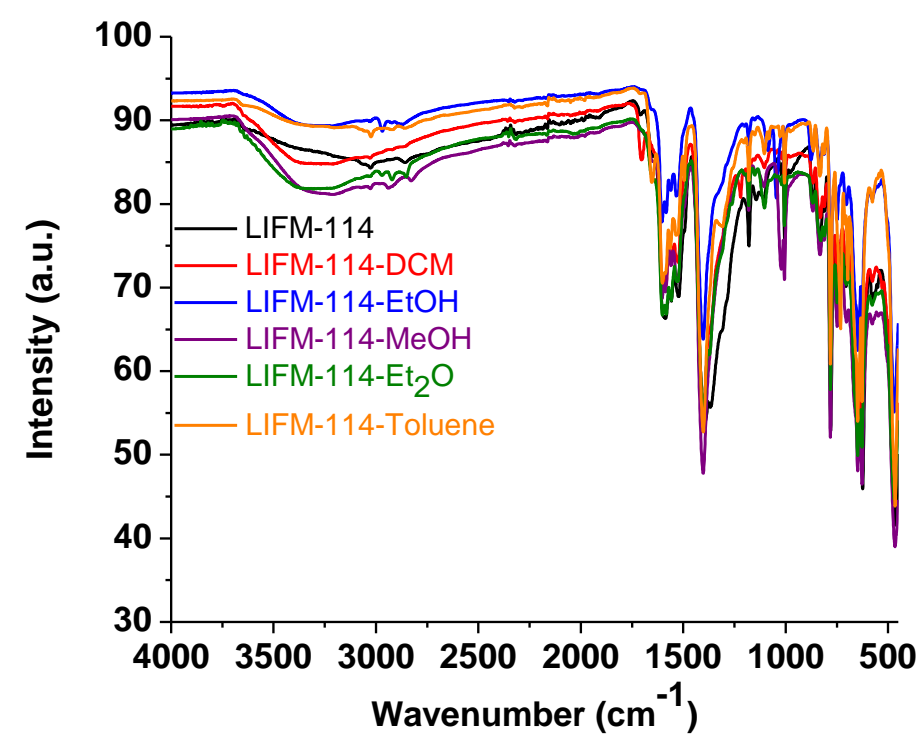

Figure S44. The Fourier-Transform Infra-Red (FT-IR) spectra of LIFM-114, and LIFM-114-S ( $\mathrm{S}=\mathrm{DCM}$, EtOH, $\mathrm{MeOH}, \mathrm{Et}_{2} \mathrm{O}$, Toluene).

LIFM-114 FT-IR (KBr, cm ${ }^{-1}$ ): 3026 (w, H2O), 2858 (w, DMF), 1586 (s, DMF), 1557 (m, DMF), 1521 (m), 1394 (s, DMF), 1367 (s), 1179 (w), 1143 (w), 1105 (w), 1019 (w), $1004(\mathrm{w}), 978$ (s), 861 (m), 831 (m), 810 (w), 781 (s), 749 (m), 705 (w), 638 (s), $624(\mathrm{~s}), 578(\mathrm{w}), 463(\mathrm{~s}), 459(\mathrm{~s})$.

LIFM-114-DCM FT-IR (KBr, cm ${ }^{-1}$ ): 3212 (w), 1601 (m), 1558 (m), 1525 (m), 1402 (s), 1220 (w, DCM), 1180 (w), 1005 (m), 866 (w), 830 (m), 781 (s), 748 (m), 703 (w), 648 (s), $627(\mathrm{~s}), 576(\mathrm{w}), 467$ (s).

LIFM-114-EtOH FT-IR (KBr, cm $\left.{ }^{-1}\right): 2968$ (w, EtOH), 1603 (m), 1557 (m), 1534 (m), 1402 (s), 1179 (w), 1087 (w), 1045 (m, EtOH), 1005 (m), 875 (w), 834 (m), 781 (s), $747(\mathrm{~m}), 703(\mathrm{w}), 647(\mathrm{~s}), 627(\mathrm{~s}), 470(\mathrm{~s})$.

LIFM-114-MeOH FT-IR (KBr, cm ${ }^{-1}$ ): 3209 (w), 1603 (m), 1559 (m), 1528 (m), 1403 (s), 1180 (w), 1105 (w, MeOH), 1020 (m), 1005 (m), 866 (w), 832 (m), 781 (s), $748(\mathrm{~m}), 703(\mathrm{w}), 648(\mathrm{~s}), 627(\mathrm{~s}), 466(\mathrm{~s})$.

LIFM-114-Et 2 O FT-IR (KBr, cm $\left.{ }^{-1}\right): 3304$ (w), 1601 (m), 1558 (m), 1531 (m), 1403 (s), $1180(\mathrm{w}), 1126$ (s, Et $2 \mathrm{O}), 1103$ (w), 1005 (m), 828 (m), 781 (s), 748 (m), 703 (w), $648(\mathrm{~s}), 628(\mathrm{~s}), 468(\mathrm{~s})$. 
LIFM-114-Toluene: 3024 (w), 1653 (m), 1601 (m), 1564 (m), 1534 (m), 1494 (m, Toluene), 1402 (s), 1179 (w), 1103 (w), 1005 (m), 864 (w), 833 (m), 781 (s), 731 (m), $696(\mathrm{w}), 648(\mathrm{~s}), 627(\mathrm{~s}), 576(\mathrm{w}), 466(\mathrm{~s})$. 